\title{
THE UNiTED NATIONS HuMAN RIGHTS COUNCIL: IS THE UNITED STATES RIGHT TO LEAVE THIS CLUB?
}

\author{
SARAH JOSEPH AND ELEANOR JENKIN*
}

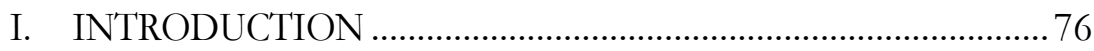

II. WHAT IS THE COUNCIL, AND WHAT DOES IT DO?78

A. MEMBERSHIP OF THE COUNCIL ........................................... 79

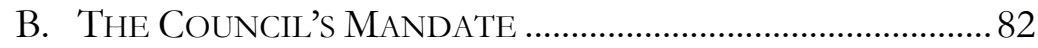

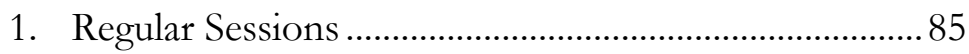

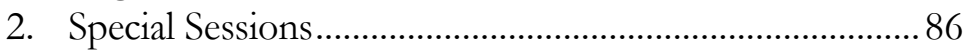

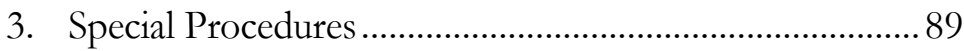

4. Universal Periodic Review .................................................... 94

5. Complaints Procedures ………………………………........ 96

C. THE AdVISORY COMMITTEE.................................................... 97

D. THE Role Of NGOs .............................................................. 97

III. WHY DOES THE COUNCIL FUNCTION SUB-

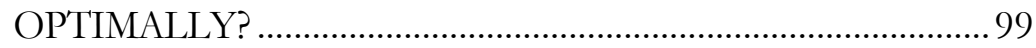

A. Membership........................................................................... 99

B. Politicization, Selectivity, And Double

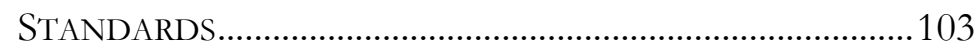

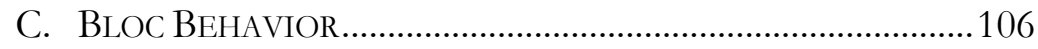

D. THE SOVEREIGNTY DIVIDE …………………………........107

E. A STUdy In Dysfunction: THE HumAn Rights

COUNCIL AND ISRAEL ……………………………….......112

IV. FIXING THE COUNCIL ………………………………….......117

A. Case Study: SeXual Orientation AND Gender

IDENTITY RIGHTS AT THE COUNCIL...................................117

1. Key SOGI milestones at the HRC ................................117

* Sarah Joseph is a Professor of Human Rights Law at Monash University, Melbourne, and the Director of the Castan Centre for Human Rights Law. Eleanor Jenkin was the Policy Manager at the Castan Centre, and now works at Victoria Legal Aid. Professor Joseph and I would like to thank Asher Hirsch for his work on the footnotes for this paper. 
2. Factors driving SOGI progress ......................................121

B. SALVAGING THE COUNCIL ................................................123

1. More principles, less politics........................................123

2. Leadership from the Global South...............................124

3. Rethinking the roles of Western States.........................125

4. Crossing Bloc Divides ......................................................127

5. Bolstering the participation of NGOS..........................128

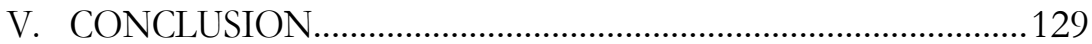

\section{INTRODUCTION}

The United Nations (UN) Human Rights Council is the world's key intergovernmental body dealing with human rights. It was created in 2006 to replace the UN Commission on Human Rights. ${ }^{1}$ Its broad mandate empowers it to address the human rights situation in any State and on any human rights issue. ${ }^{2}$ Since its creation, it has made significant strides in the development, promotion and protection of human rights. ${ }^{3}$

Yet, on June 19, 2018, Ambassador Nikki Haley, the then-United States (US) Permanent Representative to the United Nations,

1. See Economic and Social Council Res. 2006/2, T4 (Mar. 24, 2006); U.N. Secretary-General, A More Secure World: Our Shared Responsibility, Report of the High Level Panel on Threats, Challenges and Change, ๆף 289-91, U.N. Doc A/59/565 (Dec. 2, 2004) [hereinafter A More Secure World: Our Shared Responsibility]; U.N. Secretary-General, In Larger Freedom: Development, Security and Human Rights for All, $\uparrow \uparrow 181-83$, U.N. Doc. A/59/2005 (Mar. 21, 2005) [hereinafter In Larger Freedom: Development, Security and Human Rights for All; Nico Schrijver, The UN Human Rights Council: A New 'Society of the Committed' or Just Old Wine in New Bottles?, 20 LEIDEN J. INT'L L. 809, 809 (2007).

2. See U.N. Hum. Rts. Council, HRC Briefing Note (Jan. 4, 2009), https://www.ohchr.org/EN/HRBodies/HRC/RegularSessions/Session34/Docume nts/HRCBasicFacts.pdf (outlining the powers accorded to the HRC including its ability to "address any human rights issue brought to its attention").

3. See Ted Piccone, Assessing the United Nations Human Rights Council, BroOKINGS (May 25, 2017), https://www.brookings.edu/testimonies/assessing-the-unitednations-human-rights-council/ ("Since its establishment in 2006, the Human Rights Council has carried out its mission ... in a myriad of both traditional and innovative ways. These include public scrutiny of every country's human rights performance... special sessions devoted to addressing gross and systematic violations ... fact-finding investigations; country visits by independent experts charged with monitoring issues ranging from violence against women to freedom of expression; and technical assistance and capacity-building."). 
announced the US' withdrawal from the Council. ${ }^{4}$ Ambassador Haley and Secretary of State Mike Pompeo listed the continued membership of States "with unambiguous and abhorrent human rights records," the Council's failure to scrutinize the world's most inhumane regimes, and its "chronic bias against Israel" as reasons for the withdrawal. ${ }^{5}$ These criticisms are not new, and they are not without merit. ${ }^{6}$ Indeed, the same criticisms plagued the Council's predecessor, the Commission. ${ }^{7}$

However, these criticisms also reveal the extent to which the Council is misunderstood. Many reform suggestions-including those advanced by the US-have focused on strengthening its membership criteria. ${ }^{8}$ We believe that such suggestions miss the mark. They do not address fundamental structural reasons which explain why the Council acts as it does. The Council is a political body, so it is hardly surprising that its members act in a political way. Whether one likes it or not, the Council reflects the globe that we live in today, not the Western-dominated globe of the colonial yesteryear or the world as Western liberal democracies might like it to be.

\footnotetext{
4. See Carol Morello, U.S. Withdraws from U.N. Human Rights Council over Perceived Bias Against Israel, WAsH. POST (June 19, 2018), https://www.washingtonpost.com/world/national-security/us-expected-to-backaway-from-un-human-rights-council/2018/06/19/a49c2d0c-733c-11e8-b4b7308400242c2e_story.html.

5. Sec'y of State Mike Pompeo and Ambassador Nikki Haley, Remarks on the U.N. Human Rights Council June 19, 2018) (transcript available at https://www.state.gov/remarks-on-the-un-human-rights-council/).

6. See Krishnadev Calamur, The UN Human Rights Council is a Deeply Flawed Body, THE ATLANTIC June 20, 2018), https://www.theatlantic.com/international/archive/2018/06/us-un-humanrights/563276/ (highlighting the validity of many of the common criticisms of the U.N. Human Rights Council and noting that these extend back to the Bush presidency).

7. See, e.g., Rosa Freedman, The United Nations Human Rights Council: More of the Same?, 31 WIS. INT'L L. J. 208, 209 (2013) [hereinafter Freedman, The United Nations Human Rights Council: More of the Same?] (criticizing the U.N. Commission on Human Rights for its "selectivity, bias, and partiality"); Eric Heinze, Even-handedness and the Politics of Human Rights, 21 HARV. HUM. RTS. J. 7, 10 (2008) ("[A]n international body formally charged with making neutral pronouncements on human rights, such as the former U.N. Human Rights Commission, can be shown to have acted illegitimately through political bias.").

8. See generally Press Release, General Assembly, Solution to Reform of Security Council 'Is in Your Hands,' General Assembly President Says as Member States Begin Annual Debate on Long-Standing Issue, U.N. Press Release GA/11022 (Nov. 11, 2010) (discussing membership criteria and the ongoing push for reform).
} 
In this article, we explain how and why the Council functions as it does. Part One provides an outline of the Council, focusing on its composition, mandate and activities. Part Two then places the Council in its political context, including the pervasive nature of politicization within the Council, its historical and ongoing North/South divide, and reasons behind its bias against Israel. Part Three suggests a way forward. Using the example of the Council's treatment of sexual orientation and gender identity (SOGI) rights as a case study, we argue that to fulfill the potential of the Council and reassert its relevance, the majority of its Members must take "ownership" of human rights rather than treat it as a political football within broader North/South and other ideological divides. Part Four concludes this article.

\section{WHAT IS THE COUNCIL, AND WHAT DOES IT DO?}

Created in 2006, the UN Human Rights Council is the key global intergovernmental human rights body. ${ }^{9}$ Its importance within the UN framework is demonstrated by its status as a body which reports directly to the UN General Assembly. ${ }^{10}$ It has a wide mandate to promote, protect and develop human rights, which covers all states and all human rights issues. ${ }^{11}$ Nonetheless, it is often criticized for its failure to properly address human rights breaches and protect victims. ${ }^{12}$ This section will outline the composition and mechanisms of the Council, as a prelude to uncovering whether the criticisms are well-placed.

9. See E.S.C. Res. 2006/2, supra note 1, I 4; A More Secure World: Our Shared Responsibility, supra note 1, 9 - 289-91; In Larger Freedom: Development, Security and Human Rights for All, supra note 1, ๆๆ 181-83; Schrijver, supra note 1, at 809.

10. See G.A. Res. 60/251, \16 (Apr. 3, 2006) ("Decides further that the Council shall review its work and functioning five years after its establishment and report to the General Assembly." [emphasis original]). Its predecessor, the United Nations Commission on Human Rights, was a subsidiary of the UN Economic and Social Council, so it did not report directly to the UN General Assembly.

11. See G.A. Res. 60/251, supra note 10, 9 ๆ 2, 5 ([T] he Council shall be responsible for promoting universal respect for the protection of all human rights and fundamental freedoms for all. ...").

12. See, e.g., Morello, supra note 4 (discussing the Trump Administration's opposition to the Council with statements from then-Ambassador Haley and Secretary Pompeo). 


\section{A. Membership of THE COUNCIL}

The Council is composed of 47 Member States. ${ }^{13}$ In replacing the Commission with the Council, the UN updated the memberships allocated to the various regions according to the principle of "equitable geographical distribution." 14 The allocations within the Commission had, for example, given too much weight to the Western Europe and Other Group (WEOG) and too little to Asia. ${ }^{15}$ The allocations of seats at the Council are: Africa with 13 seats, Asia 13, Eastern Europe 6, Latin America 8, and WEOG 7 seats. ${ }^{16}$ This means that Africa and Asia hold over half of the seats (26 in all) between them, meaning "[i]n short, Afro-Asia can call the shots on the Council." " The redistribution of seats has seen power shift within the Council to States which favor a less robust and confrontational approach to human rights violations. Yet any other allotment would be difficult to justify, given the reality of population distribution in the world. Indeed, strict distribution according to population would result in Asia having over half of the seats on its own. ${ }^{18}$

Member States are elected by the UN General Assembly to serve for three years and a maximum of two consecutive terms. ${ }^{19}$ The latter condition is a welcome innovation. There were no term limits on the Commission. ${ }^{20}$ China (though for a long time in the form of Taiwan) and Russia (or USSR) sat constantly on the Commission, and the US only

13. G.A. Res. $60 / 251$, supra note $10,97$.

14. G.A. Res. 60/251, supra note 10, 14.

15. See Press Release, General Assembly, General Assembly Establishes New Human Rights Council by Vote of 170 in Favour to 4 Against, with 3 Abstentions, U.N. Press Release GA/10449 (Mar. 15, 2006) [hereinafter General Assembly Establishes New Human Rights Council] (detailing the Council's attempts to resolve the "longstanding problem of underrepresentation of Asian countries in the Human Rights Commission").

16. G.A. Res. 60/251, supra note 10 , ๆ 7 .

17. Bertrand G. Ramcharan, The Law, Policy and Politics of the UN HumAN RightS COUNCIL 145 (2015).

18. See Asia Population 2019, World Population Rev. (May 12, 2019), http://worldpopulationreview.com/continents/asia-population/ (last visited June 15, 2019) ("Asia comprises a full $30 \%$ of the world's land area with $60 \%$ of the world's current population.").

19. G.A. Res. 60/251, supra note 10, ๆ 7 .

20. See General Assembly Establishes New Human Rights Council, supra note 15 (providing that term limits would give all of the Council's "members the opportunity to serve, and the Council would be more representative. In short, the Council would have legitimacy in membership and decisions."). 
missed one year. ${ }^{21}$ It is desirable to have fluctuating membership and for dominant voices to sometimes be absent. ${ }^{22}$

Council members are elected by a majority of the UN General Assembly in a secret ballot. ${ }^{23} \mathrm{~A}$ region risks losing a seat if it presents an unacceptable candidate with no alternatives. It was hoped that this system would discourage "clean slates", where the number of candidates presented by a UN region corresponds with the number of seats available to it in an election. ${ }^{24}$ The system was meant to encourage genuine choices and votes. ${ }^{25}$ Initially, regions responded by presenting open lists so the General Assembly accordingly rejected notorious abusers such as Azerbaijan, Belarus and Sri Lanka in favor of more deserving rival candidates. ${ }^{26}$ Other major abusers have been dissuaded from ultimately standing for election, such as Syria in 2011. ${ }^{27}$ Most surprisingly, the superpower Russia was rejected in the 2016 elections for a term from 2017.28 However, clean slates from all

21. Members (1947-2006), U.N. Hum. RTS. COUnCIL MEMbership \& Bureau, https://www.ohchr.org/EN/HRBodies/CHR/Pages/Membership.aspx (last visited June 15, 2019).

22. See Conall Mallory, Membership and the UN Human Rights Council, 2 CAN. J. Hum. RTS. 1, 8-9 (2013).

23. G.A. Res. 60/251, supra note 10, 17.

24. See Toby Lamarque, 'Clean Slate' Elections Threaten the Future of the Human Rights Council, UnIVERSAL RTS. GRP. (Nov. 25, 2013), https://www.universalrights.org/blog/clean-slate-elections-threaten-the-future-of-the-human-rights-

council/ ("Elections should promote the participation of a diverse set of countries, from different regions, with different backgrounds, all of which earn their seat by demonstrating their commitment to human rights in a competitive election. Clean slates have the opposite effect.").

25. See Philip Alston, Reconceiving the UN Human Rights Regime: Challenges Confronting the New UN Human Rights Council, 7 MELB. J. INT'L L. 185, 198-99 (2006) [hereinafter Alston, Reconceiving the UN Human Rights Regime]; see also Lamarque, supra note 24 ("General Assembly resolution 60/251 establishing the Council declares that all members must be elected by secret ballot, taking into account the candidates' "contribution... to the promotion and protection of human rights". The clear implication is that election to the Council should be competitive. In other words, there should be a choice.").

26. See Hum. RTS. Watch, World Report 2013: Events of 2012 368, 404, 40910 (2013), https://www.hrw.org/sites/default/files/reports/wr2013.pdf (providing context for the human rights abuses perpetuated by Azerbaijan, Belarus, and Sri Lanka).

27. See Patrick Worsnip, Kuwait Elected to U.N. Rights Panel Instead of Syria, REUTERS (May 20, 2011), https://www.reuters.com/article/us-rights-un-councilidUSTRE74J5IO20110520 ("Syria, under pressure over its crackdown on protesters, dropped its bid for an Arab slot on the controversial panel.").

28. See Press Release, General Assembly, General Assembly, by Secret Ballot, Elects 
regions have returned as the norm. ${ }^{29}$ So far, the General Assembly has balked at the notion of depriving a region of a seat in electing Council members.

The criteria for membership to the Council is "soft." Candidate states make voluntary pledges and commitments that they will "uphold the highest standards in the promotion and protection of human rights." ${ }^{30}$ States also commit when electing members of the Council to "take into account the contribution of candidates to the promotion and protection of human rights and their voluntary pledges and commitments made thereto." 31 However the criteria are essentially unenforceable, as commitments may be mere posturing, and votes take place with a secret ballot. ${ }^{32}$ There is also evidence of votes being traded, without consideration of human rights issues. ${ }^{33}$ More rigorous membership criteria were proposed by various States and other stakeholders at the time the Council was created, but were

14 Member States to Serve Three-year Terms on Human Rights Council, U.N. Press Release GA/11848 (Oct. 28, 2006) (referring to the Russian Federation's status as an outgoing member); Julian Borger, Russia Denied Membership of U.N. Human Rights Council, THE GUARDIAN (Oct. 28, 2016), https://www.theguardian.com/world/2016/oct/28/russia-denied-membership-ofun-human-rights-council ("Russia has lost its bid to become a member of the UN's human rights council, in a defeat that reflects the diplomatic cost of its war in Syria").

29. See Eleanor Openshaw et al., Vote Trading and Sliding Standards Risk Eroding the Credibility of the Human Rights Council, INT'L SERV. HuM. RTS. (May 10, 2016), http://www.ishr.ch/news/vote-trading-and-sliding-standards-risk-eroding-credibilityhuman-rights-council (highlighting the fact that nations seeking election "often stand unopposed" and stating that because "criteria exists, electing States should carefully consider whether candidates are living up to it when casting their votes" rather than simply voting for an unopposed candidate).

30. G.A. Res. 60/251, supra note 10, ๆ9.

31. G.A. Res. 60/251, supra note 10 , $₫ 8$.

32. See Peter Splinter, Elections Without Choice: "Clean Slates" in the Human Rights Council, OpEN GLOB. Rights (Oct. 12, 2017), https://www.openglobalrights.org/election-without-choice-clean\%20slates-in-thehuman-rights-council/ ("[S]ecret ballot makes it nearly impossible to hold states to account for how they vote in HRC elections. It hides from scrutiny evidence of the widespread practice of vote trading whereby votes for election to the HRC are exchanged for other UN electoral candidacies.").

33. See, e.g., Sharri Markson, U.K. Deal to Back Saudi Arabia for U.N. Human Rights Council Exposed, THE Australian (Sept. 29, 2015), https://www.theaustralian.com.au/nation/world/uk-deal-to-back-saudi-arabia-forun-human-rights-council-exposed/news-story/9e469a9f92cd9a3fe2c778068aedb73a (providing an example of vote trading between the UK and Saudi Arabia). 
not adopted. ${ }^{34}$ The topic of membership criteria is revisited in Part 2.

A State may be suspended from the Council by a vote of two thirds majority of the General Assembly if it is found to have committed "gross and systematic violations of human rights." ${ }^{35}$ Libya was suspended from the Council in 2011 as a response to the crackdown by its then government on protesters and later armed rebel groups within the country. ${ }^{36}$ Libya's position on the Council was restored after the overthrow of that government. ${ }^{37}$ The risk of the ignominy of suspension perhaps provides some disincentive against the gravest abusers seeking membership.

\section{B. The COUnCIL'S MANDATE}

The Council conducts regular and special sessions, at which it passes resolutions which can relate to any aspect of human rights. ${ }^{38}$ They can be passed with respect to a State or region or be a resolution on a particular human rights issue. Most of the Council's substantive resolutions are passed by consensus and are characterized by broad statements supporting relatively uncontentious aspects of human rights. However, contentious issues do arise, particularly resolutions condemning particular States. Resolutions are not legally binding, ${ }^{39}$

34. See generally Alston, Reconceiving the UN Human Rights Regime, supra note 25, at 19394 (outlining the various suggested, but unimplemented, criteria).

35. G.A. Res. 60/251, supra note 10, \8.

36. Press Release, General Assembly, General Assembly Suspends Libya from Human Rights Council, U.N. Press Release GA/11050 (Mar. 1, 2011) ("[T]he United Nations General Assembly suspended Libya's membership in the Human Rights Council, the Organization's pre-eminent human rights body, expressing its deep concern about the situation in that country in the wake of Muammar Al-Qadhafi's violent crackdown on anti-Government protestors").

37. Member States Vote to Reinstate Libya as Member of U.N. Human Rights Council, U.N. NEWS (Nov. 18, 2011), https://news.un.org/en/story/2011/11/395392-memberstates-vote-reinstate-libya-member-un-human-rights-council ("United Nations Member States voted overwhelmingly today to readmit Libya as a member of the UN Human Rights Council, eight months after the North African country was suspended for its then government's violent repression of a popular protest movement").

38. See generally Permanent Mission of Switz. TO THE U.N. OfF., THE Human Rights COUnCIL: A PRACTICAL Guide 8-10 (2015) [THE Human RigHTS COUNCIL: A PRACTICAL GUIDE], https://www.eda.admin.ch/dam/eda/en/documents/publications/InternationaleOrg anisationen/Uno/Human-rights-Council-practical-guide_en (providing background information on the Council's regular and special sessions).

39. The Human Rights Council: A Practical Guide, supra note 38, at 5 ("The 
but they carry significant political and moral weight, particularly if passed by consensus or a large majority. ${ }^{40}$

Since its inception, the Council has adopted significant new human rights standards and procedures. For example, it adopted new human rights treaties to combat disappearances ${ }^{41}$ and to promote and protect the rights of people with a disability. ${ }^{42}$ It adopted the Declaration on the Rights of Indigenous Peoples in 2007, ${ }^{43}$ after that instrument had stalled for over a decade. ${ }^{44}$ It has adopted important new standards for human rights implementation, such as the 'Guiding Principles on business and human rights'. ${ }^{45}$ Finally, individual complaints systems have been created for core UN treaties where they previously did not exist. $^{46}$

The Council's powers of 'enforcement' lie in the process of naming and/or shaming a State that is engaged in human rights abuses. ${ }^{47} \mathrm{No}$

HRC ... resolutions and decisions are not legally binding but do contain strong political commitments").

40. The Human Rights Council: A Practical Guide, supra note 38, at 5, 18 (highlighting the importance of the HRC resolutions status as the non-binding "political expression of the views of its members").

41. G.A. Res. 61/177, International Convention for the Protection of All Persons from Enforced Disappearance (Dec. 20, 2006).

42. G.A. Res. 61/106, Convention on the Rights of Persons with Disabilities (Dec. 13, 2006).

43. G.A. Res. 61/295, annex, United Nations Declaration on the Rights of Indigenous Peoples 1-2 (Sept. 13, 2007).

44. See, e.g., Doug Cuthand, Bill on Indigenous Peoples' Rights Being Stalled, THE TELEGRAM June 15, 2019), https://www.thetelegram.com/opinion/columnists/doug-cuthand-bill-onindigenous-peoples-rights-being-stalled-322763/ ("The United Nations Declaration on the Rights of Indigenous Peoples was adopted by the UN General Assembly in 2007 after two decades of negotiations and deliberations within the organization.").

45. See Special Representative of the Secretary-General, Guiding Principles on Business and Human Rights: Implementing the United Nations "Protect, Respect and Remedy" Framework, U.N. Doc. A/HRC/17/31, annex, 6 (Mar. 21, 2011) [hereinafter Guiding Principles on Business and Human Rights] (providing the foundation upon which the guiding principles on business and human rights are grounded).

46. See generally Optional Protocol to the International Covenant on Economic, Social and Cultural Rights, art. 2 (Dec. 10, 2008); G.A. Res. 66/138, annex, Optional Protocol to the Convention on the Rights of the Child on a Communications Procedure, art. 5 (Dec. 19, 2011).

47. Sarah Joseph \& Joanna Kyriakakis, The United Nations and Human Rights, in RESEARCH HANDBOOK ON INTERNATIONAL HuMAN Rights LAw 1, 26 (Sarah Joseph \& Adam McBeth eds., 2010) ("None of the human rights institutions discussed above are able to make legally binding decisions, unlike, for example, the regional human 
government relishes being the subject of such shaming processes, and even the most powerful States will lobby to avoid such consequences. ${ }^{48}$ Beyond embarrassment, shaming is sometimes the first step towards the adoption of stronger-either unilateral or multilateral-measures against a State. ${ }^{49}$ It can galvanize local civil society organizations and lend credibility to domestic opposition groups. ${ }^{50}$ It can prompt further pressure from other States, public protests, the media, and non-government organizations (NGOs). ${ }^{51}$ Other States can find themselves the target of secondary pressure to 'do something' about the shamed State, placing strain on a relevant alliance, and even on diplomatic relations. ${ }^{52}$ Corporations might be pressured to withdraw investments from a delinquent State, or to not invest in the first place. ${ }^{53}$ While shaming may not, in many circumstances, lead to immediate changes in behavior by target States, it can have a long-term corrosive effect on a delinquent government, playing a role in a government's change in behavior or ultimate demise. $^{54}$

rights courts. Their powers of 'enforcement' lie in the process of naming and shaming a State that is engaged in human rights abuses").

48. Id. at 26 ("No government enjoys being the subject of such shaming processes, and even the most powerful States will lobby to avoid such consequences."').

49. Id. at 28 (noting that " $[\mathrm{w}]$ hile shaming is the most common form of international enforcement of human rights, the most serious human rights situations can prompt stronger unilateral and multilateral sanctions.").

50. Id. at 27 ("Beyond embarrassment, shaming can have real consequences for a government. The shaming of a government can galvanise and lend credibility to domestic opposition groups.").

51. Id. at 27 (describing how "[s] haming can prompt further pressure from other States, public protests, the media, and NGOs.").

52. Id. at 27 ("In extreme cases, allies of a shamed government can find themselves the target of secondary pressure to 'do something' about the shamed State, placing extreme strain on the relevant alliance.").

53. Id. at 27 ("Certain non-State actors, such as corporations that invest in a delinquent State, might be pressured to remove their investments, or to not invest in the first place."). See generally James H. Lebovic \& Erik Voeten, The Politics of Shame: The Condemnation of Country Human Rights Practices in the U.N.C.H.R., 50 INT'L STUD. Q. 861, 868-69 (2006) (highlighting how States' loss of reputation can have significant market effects).

54. See Darren G. HAWkins, International Human Rights AND AUTHORITARIAN RULE IN CHILE 74-75 (2002) (explaining how the public shaming of the Chilean government under Pinochet was in part the reason for its later fall); Joseph \& Kyriakakis, supra note 47, at 27 ("While shaming may not, in many circumstances, lead to immediate changes in behaviour by target States, it can have a long-term corrosive effect on a delinquent government, playing a role in a government's change 
The work of the Council can be divided into five main areas: regular sessions, special sessions, Special Procedures, the Universal Periodic Review, and a complaints system. We will deal with these in turn.

\section{Regular Sessions}

Regular sessions take place in Geneva three times a year, in March, June and September, for a total of ten weeks..$^{55}$ The regular agenda is dictated by Council Resolution 5/1, its "Institution-Building Resolution," 56 and consists of the following ten items:

1. Organizational and procedural matters

2. Annual report of the United Nations

3. Promotion and protection of all human rights

4. Human rights situations that require the Council's attention

5. Human rights bodies and mechanisms

6. Universal Periodic Review

7. Human rights situation in Palestine and other occupied Arab territories

8. Follow-up and implementation of the Vienna Declaration (1993)

9. Racism, racial discrimination, xenophobia and related forms of intolerance, follow-up and implementation of the Durban Declaration.

10. Technical assistance.

The agenda is ultimately very broad, enabling the Council to discuss any State and any human rights situation in the world. The placement of topics under particular agenda items frames the manner in which those topics are dealt with. ${ }^{57}$ Hence, it can be manipulated by Members to

in behaviour or ultimate demise.").

55. See Human Rights Council Res. 5/1, annex, U.N. Doc. A/62/53, at 65 June 18, 2007).

56. H.R.C. Res. 5/1, supra note 55, at 61 .

57. See generally Ellis Heasley, Moving On Up: The UN Human Rights Council Agenda 
confine debate within artificially narrow limits. For example, discussions of country-specific situations can be watered down by taking place under Item 10, which emphasizes a cooperative and facultative role for the Council in its dealing with a State, rather than under Item 4, which entails a more robust discussion of a State's flaws. ${ }^{58}$

Item 7 specifies the only country situation which occupies part of the regular agenda, the situation in the West Bank, Gaza and the Golan Heights. While the human rights situation in that area is serious, it is anomalous that any particular situation is designated as part of the Council's regular discussions. ${ }^{59}$ Item 7 is one example of the Council's apparent bias against Israel, one of the major causes of dissatisfaction with the institution (and its predecessor) and the US withdrawal. ${ }^{60} \mathrm{We}$ return to this issue below.

\section{Special Sessions}

A special session of the Council may be called by one-third of its membership, enabling it to respond quickly to human rights

Items Explained, FreEDOM OF RELIGION OR BELIEF IN FULL: A BLOG BY CSW (Oct. 24, 2018), https:// forbinfull.org/2018/10/24/moving-on-up-the-un-human-rightscouncil-agenda-items-explained/ (describing how items listed under agenda item 4 are typically understood to be more pressing than those listed under agenda item 10).

58. Human Rights Council: Stalled Momentum on Country Responses Partly Offset by Thematic Advances, HuM. RTS. MONITOR Q. 1, 4 (2011), https://www.ishr.ch/sites/default/files/hrm/files/hrmq_nov11_final.pdf (noting that "Item $10 \ldots$ focuses on provision to the State of technical cooperation and capacity building ... [and that] Item 4 [provides a forum where] the Council can discuss situations of concern from a wider perspective than just provision of technical assistance.").

59. See Colum Lynch, U.S. Thwarted in Bid to Change U.N. Rights Council's Approach to Israel, Foreign POL'Y (May 30, 2018, 4:08 PM), https:// foreignpolicy.com/2018/05/30/u-s-thwarted-in-bid-to-change-u-n-rightscouncils-approach-to-israel/ (pointing out that "[n]o other part of the world has its own agenda item."); see also U.N. Human Rights Council, Human Rights Council Holds General Debate on the Human Rights Situation in Palestine and Other Occupied Arab Territories - Press Release (July 2, 2018), https://www.un.org/unispal/document/human-rights-council-holds-general-debateon-the-human-rights-situation-in-palestine-and-other-occupied-arab-territories-pressrelease-2/ (highlighting the severity of the human rights abuses going on in the countries referenced by Item 7).

60. Colum Lynch, U.S. Thwarted in Bid to Change U.N. Rights Council's Approach to Israel, FOREIGN POL'Y (May 30, 2018), https://foreignpolicy.com/2018/05/30/u-sthwarted-in-bid-to-change-u-n-rights-councils-approach-to-israel/. 
emergencies during the times in which it is not sitting, ${ }^{61}$ or to simply devote particular attention to a serious human rights crisis. By the end of 2018, the Council had held 28 special sessions on:

1. Human rights situation in the Occupied Palestinian Territories (2006)

2. Israeli military action in Lebanon (2006)

3. Israeli military action in the Occupied Palestinian Territories (2006)

4. Human rights in Darfur (2006)

5. Human rights in Myanmar (2007)

6. Israeli military action in the Occupied Palestinian Territories (2008)

7. World food crisis (2008)

8. Democratic Republic of the Congo (2008)

9. Israeli military action in Gaza (2009)

10. Global economic and financial crisis (2009)

11. Human rights in Sri Lanka (2009)

12. Israel and the Occupied Palestinian Territories, and East Jerusalem (2009)

13. Human rights and recovery in Haiti (2010)

14. Human rights in Côte d'Ivoire (2010)

15. Human rights in Libya (2011)

16. Human rights in Syria (2011)

17. Human rights in Syria (2011)

18. Human rights in Syria (2011)

19. Human rights in Syria (2012)

61. G.A. Res. 60/251, ๆ 16 (Mar. 15, 2006). 
20. Human rights in the Central African Republic (2014)

21. Human Rights situation in the Occupied Palestinian Territory, including East Jerusalem (2014)

22. Human Rights situation in Iraq in light of abuses committed by the Islamic State in Iraq and the Levant and associated groups (2014)

23. Terrorist attacks and human rights abuse and violations committed by the terrorist group Boko Haram (2015)

24. Preventing further deterioration of the human rights situation in Burundi (2015)

25. The deteriorating situation of human rights in the Syrian Arab Republic, and the recent situation in Aleppo (2016)

26. Human rights situation in South Sudan (2016)

27. Rohingya and other minorities in Rakhine State in Myanmar (2017)

28. The deteriorating situation of human rights in the occupied Palestinian territory, including East Jerusalem (2018)

Two country situations dominate this list. Understandably, given the vicious civil war in Syria which has killed hundreds of thousands since $2011,{ }^{62}$ there have been five special sessions devoted to that State. ${ }^{63}$ The other situation dominating such proceedings is Israel and the Occupied Territories, which has been the subject of eight special sessions. ${ }^{64}$ Three of those sessions concerned significant armed conflicts, notably Israel's incursions into Lebanon in 2006 and Gaza in late 2008 and 2014, which justified special attention. ${ }^{55}$ However, the need for an extra five special sessions, especially when there is a relevant regular agenda item, is doubtful. This is another alleged manifestation of the anti-Israel bias,

62. Megan Specia, How Syria's Death Toll is Lost in the Fog of War, N.Y. TIMES (Apr. 13, 2018), https://www.nytimes.com/2018/04/13/world/middleeast/syria-deathtoll.html.

63. U.N. Hum. Rts. Council, Special Sessions, https://www.ohchr.org/EN/HRBodies/HRC/SpecialSessions/Pages/SpecialSession s.aspx (last visited Sept. 20, 2019).

64. Id.

65. Id. 
which we discuss below.

Also notable are the crisis situations not listed above, such as the ongoing war in Yemen ${ }^{66}$ massacres in Egypt,${ }^{67}$ the civilian casualties in the war against Islamic State in Mosul in Iraq, ${ }^{68}$ and the violent crime in Mexico that has killed tens of thousands over the last decade. ${ }^{69}$ As explained below, the Council is commonly criticized for selectivity, which is manifested both by disproportionately targeting certain States and situations, and by neglecting certain severe abuses, such as those just mentioned.

\section{Special Procedures}

The Council has built on the Commission's system of special procedures, consisting of special experts (known as "special rapporteurs" or "independent experts") and working groups, which was developed over the last forty years. ${ }^{70}$ Special procedures can be created to examine a particular human rights issue or the human rights situation in a particular State.

At the end of 2018, there were 44 thematic and eleven country mandates. ${ }^{71}$ The thematic mandates variously focus on particular civil and political rights (e.g. freedom from torture, freedom of expression), economic social and cultural rights (e.g. right to culture, right to food), particular categories of rights-holders (e.g. migrants, indigenous peoples), the environment (right to a healthy environment, disposal of toxic waste), particular causes of human

66. Yemen Crisis: Why is There War?, BBC News (Mar. 21, 2019), https://www.bbc.com/news/world-middle-east-29319423.

67. Egypt: Five Years Since 'Rabaa Massacre', AL JAZEERA (Aug. 14, 2018), https://www.aljazeera.com/news/2018/08/egypt-years-rabaa-massacre180813145929087.html?xif=.

68. Samuel Oakwood, Counting the Dead in Mosul, The ATLANTiC (Apr. 5, 2018), https://www.theatlantic.com/international/archive/2018/04/counting-the-dead-inmosul/556466/.

69. Kate Linthicum, More and More People are Being Murdered in Mexico - and Once More Drug Cartels are to Blame, L.A. Times (Mar. 3, 2017), https://www.latimes.com/world/mexico-americas/la-fg-mexico-murders-20170301story.html.

70. Aoife Nolan et al., The United Nations Special Procedures System, BrILL (Aoife Nolan et al. eds., 2017).

71. U.N. Off. of the High Comm'r for Hum. Rts, Special Procedures of the Human Rights Council, https://www.ohchr.org/EN/HRBodies/SP/Pages/Introduction.aspx (last visited on Sept. 20, 2019). 
rights abuse (e.g. transnational corporations, mercenaries), or on North/South economic justice issues (creation of an equitable international order, human rights and foreign debt, extreme poverty and international solidarity). ${ }^{72}$ Most of these mandates have carried over from the Commission, though the Council has created over a quarter itself. ${ }^{73}$ Some of the mandates could possibly be merged to save resources. For example, the toxic waste mandate could now perhaps be incorporated within the broader (newer) mandate on a clean environment. However, it is politically difficult to drop thematic mandates which might correspond with the pet issues of specific States. $^{74}$

The country-related mandates are more controversial. Naturally, no State likes being singled out for a special procedure. Some influential States, such as China, Cuba and Egypt, are historically opposed to country mandates as a matter of principle. ${ }^{75}$ Indeed, there was some concern that the Council, upon its establishment, might abolish such mandates altogether. ${ }^{76}$ This did not happen, but it did look for a while as if the country mandate system might simply erode away. ${ }^{77}$ No new mandates were created in the Council's first five years, ${ }^{78}$ while mandates on Liberia, Belarus, Cuba, and the Democratic Republic of the Congo were discontinued, ${ }^{79}$ and the Sudan mandate hung by a thread, renewed for diminishing periods of time. ${ }^{80}$ However, the Council changed course in 2011 when a new mandate for the Islamic Republic of Iran was created, followed by new mandates for Côte d'Ivoire, Eritrea, Mali and the return of a special procedure for Belarus. ${ }^{81}$

At the end of 2018, there were eleven mandates to investigate the

72. $I d$.

73. Marc Limon \& Hilary Power, History of the United Nations Special Procedure Mechanism: Origins, Evolution and Reform, UnIVERSAL RTS. GRP. 10 (Sept. 2014), https://www.universal-rights.org/wpcontent/uploads/2015/02/URG_HUNSP_28.01.2015_spread.pdf.

74. See Alston, Reconceiving the UN Human Rights Regime, supra note 25, at 216.

75. Id. at 205-06.

76. See Limon \& Power, supra note 73 , at 10.

77. Id.

78. $I d$.

79. Id.

80. Id.

81. Id. 
following States: Belarus, Cambodia, Central African Republic, Eritrea, North Korea, Iran, Mali, Myanmar, Somalia, Sudan, and the situation of human rights in the Palestinian Territories. ${ }^{82}$ Unlike thematic mandates, which are generally renewed for three years, ${ }^{83}$ country mandates are usually renewed only for one year, ${ }^{84}$ so the Council has more opportunities to reconsider and possibly terminate them. However, the Palestinian mandate was established in 1993 to last until the end of the Israeli occupation, so it is never subjected to a vote over its renewal. ${ }^{85}$ Another distinguishing feature of this mandate is its one-sidedness; it only concerns human rights in the Occupied Territories rather than Israel itself, and only the behavior of Israel rather than that of the Palestinian authorities or Hamas. ${ }^{86}$ Hence, the special opprobrium which the Council reserves for Israel is reflected in the special procedures too.

The reports arising from the Special Procedures themselves are an invaluable source of factual, legal and normative material. Thematic special procedures produce reports on specific themes under their mandate, as well as reports summarizing their findings from visits to particular States. ${ }^{87}$ These reports play a pivotal role in elaborating and advancing human rights standards, including, in recent times, on such valuable topics as the right to life and the use of force by private security providers ${ }^{88}$ freedom of expression and the internet, ${ }^{89}$ as well as in the

82. U.N. Hum. Rts. Council, President's statement, Situation of human rights in Haiti, U.N. A/HRC/PRST/34/1 (Apr. 3, 2017).

83. U.N. Off. of the High Comm'r for Hum. Rts., Working with the United Nations Human Rights Programme: A Handbook for Civil Society, HR/PUB/06/10/Rev.1, 107 (2008) [Working with the United Nations Human Rights Programme], https://www.ohchr.org/en/AboutUs/CivilSociety/Documents/Handbook_en.pdf.

84. Working with the United Nations Human Rights Programme, supra note 83, at 107.

85. Country-Specific Special Procedures, INT'L JUST. RES. CTR., https://ijrcenter.org/unspecial-procedures/list-of-country-specific-special-procedures/ (last visited June 30, 2019).

86. H.R.C. Res. 1993/2, U.N. Doc E/CN.4/RES/1993/2, \4(a) (Feb. 19, 1993).

87. See Working with the United Nations Human Rights Programme, supra note 83, at 107.

88. Christof Heyns (Special Rapporteur on extrajudicial, summary or arbitrary executions), Rep. on the right to life and the use of force by private security providers in law enforcement contexts, U.N. Doc. A/HRC/32/39 (May 6, 2016).

89. Frank La Rue (Special Rapporteur), Rep. on the promotion and protection of the right to freedom of opinion and expression, U.N. Doc. A/66/290 (Aug. 10, 2011). 
digital age,${ }^{90}$ the right of everyone to mental health, ${ }^{91}$ the protection of whistle-blowers, ${ }^{92}$ and the impact of gender on enjoyment of the right to food.$^{93}$ It is however difficult to identify concrete reforms generated by Special Rapporteurs at the country level. States will rarely admit that they have "seen the light" after a fact-finding visit from a mandate holder. ${ }^{94}$ Nevertheless, the compilation and issuance of mandate holders'reports may contribute significantly to human rights dialogue with and within a State.

Mandate holders serve in their independent expert capacity rather than as government representatives. ${ }^{95}$ The relationship between the Council and the mandate holders themselves has at times been fractious. ${ }^{96}$ While some States extend standing invitations to all thematic special procedures, others refuse to allow mandate holders to conduct fact-finding activities in their territories. ${ }^{97}$

In 2007, the Council adopted the Code of Conduct for Special Procedures Mandate-Holders of the Human Rights Council..$^{98}$ Many of the principles therein are arguably unobjectionable, but it represents an effort by some States to constrain the mandate-holder's discretion in choosing how to do their job and to elevate the value of State information over those of non-state actors. ${ }^{99}$ The Code also gives the impression that the conduct of mandate-holders is of greater

90. David Kaye (Special Rapporteur), Rep. on the promotion and protection of the right to freedom of opinion and expression, U.N. Doc. A/HRC/32/38 (May 11, 2016).

91. Special Rapporteur, Rep. on the right of everyone to the enjoyment of the bighest attainable standard of physical and mental health, U.N. Doc. A/HRC/35/21 (Mar. 28, 2017).

92. David Kaye, (Special Rapporteur), Rep. on the promotion and protection of the right to freedom of opinion and expression, U.N. Doc. A/70/361 (Sept. 8, 2015).

93. Special Rapporteur, Rep. on the right to food, U.N. Doc. A/HRC/31/51 (Dec. 14, 2015).

94. Poverty Causing 'Misery' in U.K., and Ministers are in Denial, Says U.N. Official, BBC (Nov. 16, 2018), https://www.bbc.com/news/uk-46236642.

95. Marc Limon \& Ted Piccone, Human Rights Special Procedures: Determinants of Influence, UNIVERSAL RTS. GRP. 2 (Mar. 2014).

96. Limon \& Piccone, supra note 95, at 2.

97. Heather Collister, Human Rights Council: Persistent Non-Cooperation from some States, INT'L SERV. HuM. RTS. (June 20, 2014), https://www.ishr.ch/news/human-rightscouncil-persistent-non-cooperation-some-states.

98. H.R.C. Res. 5/2, U.N. Doc. A/HRC/RES/5/2 (June 18, 2007).

99. U.N. Off. of the High Comm'r for Hum. Rts., Manual of Operations of the Special Procedures of the Human Rights Council, 21-22 (Aug. 2008), https://www.ohchr.org/EN/HRBodies/SP/CoordinationCommittee/Pages/Manual ofspecialprocedures.aspx. 
pressing concern within the human rights field than the conduct of abusers. ${ }^{100}$

The Code of Conduct is now wielded by States when they are unhappy with criticism from a Special Rapporteur. For example, Kenya launched an attack on the credibility of the then-Special Rapporteur on Extrajudicial, Summary or Arbitrary Executions, Philip Alston, in the wake of his 2009 report. ${ }^{101}$ Kenya accused Alston of breaching the Code by relying on "incredible" information. ${ }^{102}$ It added: "His demeanour and hostility during his interactions with Government officials attests to the fact that his impartiality and objectivity were compromised." 103 At one point, it seemed possible that the Africa group and other members of the Council might withdraw support from Alston, effectively forcing his resignation. ${ }^{104}$ That circumstance did not eventuate. ${ }^{105}$

Alongside the special procedures, the Council also authorizes the creation of "Commissions of Inquiry" or "Fact-finding Missions," composed of independent human rights experts who investigate the most serious human rights abuses, including breaches of international humanitarian law, and make findings of fact and law. ${ }^{106}$ For example, the Council has authorized Commissions on Inquiry for Syria, Libya, North Korea, and more recently, Myanmar in the wake of genocidal violence against the Rohingya minority. Commissions on Inquiry differ from other mandates in that they are essentially investigative bodies, and they tend to report on only the most extreme human rights abuses, such as those which constitute international crimes like genocide, war crimes, and crimes against humanity. They can cover entire States or they can

100. Collister, supra note 97.

101. Gakuu Mathenge, How Kenya Turned Africa Against Alston, STANDARD Dig. (June 20, 2009), https://www.standardmedia.co.ke/article/1144017390/how-kenyaturned-africa-against-alston.

102. Government of the Republic of Kenya, Response to the Report of the Special Rapporteur on Extrajudicial, Arbitrary or Summary Executions, Professor Philip Alston, on his mission to Kenya from 16-25 February 2009, (May 22, 2009) [hereinafter Response to the Report of the Special Rapporteur].

103. Response to the Report of the Special Rapporteur, supra note 102.

104. Bernard Namunane \& Alphonce Shiundu, Kenyan Government plots to oust UN rapporteur Alston, HuM. RTS. HousE (June 8, 2009).

105. Namunane \& Shiundu, supra note 104.

106. See generally International Commissions on Inquiry on Human Rights, FactFinding Missions and other Investigations, https://www.ohchr.org/EN/HRBodies/HRC/Pages/COIs.aspx (last visited Sept. 17, 2019). 
focus on specific atrocities. They are designed to uncover the truth with regard to gross human rights abuses, with a view to their findings perhaps prompting and being used in international criminal proceedings. Commissions on Inquiry are not the sole preserve of the Council: other UN bodies have also established such inquiries, such as the Security Council, the General Assembly, and the Secretary-General. ${ }^{107}$

\section{Universal Periodic Review}

Universal periodic review (UPR) is the major innovation in the Council's work compared to the Commission. ${ }^{108}$ UPR entails the review of the human rights record of each UN Member State. It takes place under the auspices of the Council but all States can take part in a review. In a State's UPR, its human rights record is assessed against the Charter of the United Nations, the Universal Declaration on Human Rights, the human rights instruments to which the reviewed State is a party, its voluntary pledges and commitments, and applicable international humanitarian law. ${ }^{109}$ The review involves consideration of information prepared by the State concerned, a compilation of relevant official UN materials (e.g. comments by treaty bodies and Special Rapporteurs on the relevant State), and a summary of other "credible and reliable information provided by other relevant stakeholders." 110 This latter document allows for the input of nongovernmental organizations (NGOs), national human rights institutions, and human rights academics.

UPR is a welcome development as every State's human rights record is reviewed, regardless of its size or political power. States parties to the various UN treaties have long been reviewed periodically by the UN treaty bodies. However, such reviews are not comprehensive because they only concern States parties to, as well as the rights in, the relevant

107. See U.N. Off. of the High Comm'r for Hum. Rts., Commissions on Inquiry and Fact-Finding Missions on International Human Rights and Humanitarian Law: Guidance and Practice (2015) https://www.ohchr.org/Documents/Publications/CoI_Guidance_and_Practice.pdf; Ted Piccone, UN Human Rights Commissions of Inquiry: the Quest for Accountability, BROOKINGS (Dec. 2017).

108. U.N. Hum. Rts. Council, Universal Periodic Review, https://www.ohchr.org/en/hrbodies/upr/pages/uprmain.aspx (last visited Sept. 17, 2019).

109. H.R.C. Res. 5/1, supra note 55.

110. H.R.C. Res. 5/1, supra note 55. 
treaty. In contrast, UPR provides a hitherto unavailable opportunity for the review, for example, of China's record regarding civil and political rights, and the US's record on economic social and cultural rights. ${ }^{111}$

UPR is far from perfect. Each State's report is limited to 10,700 words, ${ }^{112}$ while the review dialogue itself takes place in half a day. Many interventions are political, with States praising their allies and excoriating their enemies. ${ }^{113}$ Some interventions contradict human rights law or are so vague as to be useless. The quality of UPR contrasts poorly with the depoliticized longer reviews undertaken of States reports by the UN treaty bodies. The reviewed State is also able to reject recommendations, no matter how sound they might be. Having said that, there is no doubt that States care what their peer States think and say about their human rights record, so UPR entails a significant measure of international human rights accountability.

There have been some moves by States to undermine the process. Worryingly, Russia successfully lobbied in 2013 for two recommendations (both made by Georgia) to be removed from official documentation on the grounds that they did "not comply with the basis of the review stipulated in [HRC] resolutions $5 / 1$ and $16 / 21 . " 114$ In that same year, Israel boycotted its own UPR, in protest against the Council's bias against it. ${ }^{115}$ In its most recent UPR in 2018, Israel attended its review but refused to participate in the subsequent

111. Universal Periodic Review, HuM. RTS. WATCH (May 2000), https://www.hrw.org/legacy/backgrounder/un/un0506/3.htm. China is not a party to the International Covenant on Civil and Political Rights (Dec. 16, 1966, 999 U.N.T.S. 171), while the US is not a party to the International Covenant on Economic, Social and Cultural Rights (Dec. 16, 1966, 993 U.N.T.S. 3).

112. U.N. Hum. Rts. Council, 3rd Cycle Periodic Review National Report Guidance Note, https://www.upr-info.org/sites/default/files/generaldocument/pdf/ohchr_guidance_national_report_3rdcycle_en.pdf (last visited Sept. 17, 2019).

113. Juliette De Rivero, Curing the Selectivity Syndrome: The 2011 Review of The Human Rights Council, Hum. RTS. WATCH (June 24, 2010), https://www.hrw.org/report/2010/06/24/curing-selectivity-syndrome/2011-reviewhuman-rights-council; Zach Zarnow, Universal Periodic Review: Problems and Potential Human Rights Brief, HuM. RTS. BRIEF (Apr. 6, 2010), http://hrbrief.org/2010/04/universal-periodic-review-problems-and-potential/.

114. Roland Chauville \& Mirza Taqi, Unprecedented Challenge to the Universal Periodic Review, INT'L SERV. Hum. RTS. (May 31, 2013), https://www.ishr.ch/news/unprecedented-challenge-universal-periodic-review.

115. Israel Boycotts U.N. Human Rights Council, AL JAZEERA (Jan. 29, 2013), https://www.aljazeera.com/news/middleeast/2013/01/2013129163929359758.html. 
adoption of its UPR report. ${ }^{116}$ Israel's no-shows set a worrying precedent which may undermine the universality and legitimacy of the UPR process.

Nevertheless, the process has improved significantly since it began in 2008. States increasingly focus their statements on useful comments and recommendations rather than on time-wasting diplomatic niceties. ${ }^{117}$ Any State can participate in any review, so reviews cannot be artificially dominated by allies or enemies. Procedural compliance, in terms of the timely delivery of reports and attendance at reviews, has been very high. While States can and do reject recommendations, many recommendations are accepted, though the entire process would benefit from greater accountability being imposed on States to implement accepted recommendations between reviews. The UPR process also stimulates important national dialogues within the States being reviewed.

\section{Complaints Procedures}

The Commission had two complaints mechanisms. The "1503" procedure was a confidential complaints procedure whereby the Commission could receive communications regarding situations that 'reveal a consistent pattern of gross and reliably attested violations of human rights' in any country or region in the world. It also adopted a public procedure, the " 1235 " procedure. In certain situations, consideration of 1503 complaints were transferred to the public 1235 procedure, which was obviously more embarrassing for the State. ${ }^{118}$ Numerous Commission special procedures were germinated by 1503 complaints.

The Council has retained and marginally improved the complaint mechanisms. Complaints still concern allegations of consistent patterns of gross and evidenced human rights violations and may be made against any State regardless of the treaties it has ratified.

116. Israel Boycotts UN Adoption of its Own Human Rights Report, HuM. RTS. WATCH (2018), https://www.hrw.org/news/2018/06/29/israel-boycotts-un-adoption-itsown-human-rights-report.

117. Subhas Gujadhur \& Marc Limon, Towards the Third Cycle of the UPR: Stick or Twist?, UNIVERSAL RTS. GRP. 26 (July 2016), https://www.universal-rights.org/wpcontent/uploads/2016/07/URG_UPR_stick_or_twist.pdf.

118. Marc Limon, Reform of the UN Human Rights Petitions System, UNIVERSAL RTS. GRP. 17 (Jan. 2018). 
Individuals, groups, and NGOs can submit complaints. Complaints remain confidential unless elevated to a public investigation. For example, the Council's confidential considerations of human rights in Eritrea ceased at its 21st session in 2012 and were transmitted to a new Special Rapporteur, whose mandate had been created in the previous session. ${ }^{119}$ A positive innovation is that the authors of complaints are now better informed of the progress of their complaint. Consideration of a complaint is also generally faster than was the case with the Commission.

\section{THE AdVISORY COMMITTEE}

The Advisory Committee to the Human Rights Council is a body made up of eighteen independent human rights experts from around the world. It provides research and advice on human rights matters as requested by the Council. In that respect, it is a less powerful body than its predecessor, the Sub-Commission on Human Rights, which advised the Commission. The Sub- Commission was able to perform work in human rights areas without a specific request from the Council, which enabled it to set its own agenda and, to a limited extent, that of the Commission. For example, the Sub-Commission's work on business and human rights, disability, and disappearances prompted actions in those areas by the Commission, which carried through to the Council. Absent a power of initiative, those issues may never have made it into the Commission/Council's program.

Therefore, the Committee is unfortunately a step backwards from the Sub-Commission. As experts acting without political motives, the Advisory Committee is better placed than the Council to identify gaps in human rights law and spearhead developments beyond the more narrow limits created by the dynamics of member State interests. ${ }^{120}$

\section{THE ROLE OF NGOS}

NGOs play an important role in the Council even though they cannot per se gain membership. ${ }^{121}$ According to Joachim Rücker, former

119. H.R.C. Res. 21/1, U.N. Doc A/HRC/RES/21/1 (Sept. 26, 2012).

120. Sarah Joseph \& Joanna Kyriakakis, The United Nations and Human Rights, RES. HANDBOOK INT'L HuM. RTS. L. 15, 26 (Sarah Joseph \& Adam McBeth eds., 2010).

121. G.A. Res. 60/251, I 16 (Mar. 15, 2006); Anne Herzberg, Submission regarding Human Rights Council Resolution 32/31 on Civil Society Space, NGO MONITOR (July 9, 
President of the Human Rights Council:

NGOs put issues on the agenda, provide vital information about human rights on the ground, and give a voice and face to human rights. NGOs assist to implement and monitor the implementation of the decisions and resolutions of the Council at the national level. NGOs are thereby often bridging the gap between the international, regional and national levels, by helping to translate our work into action, by triggering change, and by reminding us to strive for accountability. $^{122}$

Approximately 350 NGOs participate in Council proceedings ${ }^{123}$ by delivering written and oral statements, and holding and participating in panel discussions, informal meetings and parallel side events. ${ }^{124}$ In order to participate at the Council, an NGO must be accredited as an observer, generally by applying to the UN Committee of NGOs for consultative status. ${ }^{125}$ The process of accreditation is beset by a number of serious issues, not least its politicization. ${ }^{126}$ Within the Council, some States interrupt or silence NGOs by abusing points of procedure. For example, a State might continually object and interject during oral statements on the basis that an NGO's comments are outside the remit of a particular agenda item.

Despite these considerable barriers, NGOs play an influential role at the Council. According to Schokman and Lynch, 'the evidence is

2017).

122. Joachim Rücker, Importance and Impact of NGOs at the Human Rights Council, INT'L SERV. HUM. RTS. (Dec. 3, 2015), https://www.ishr.ch/news/importance-and-impactngos-human-rights-council.

123. For an illuminating study of NGOs at the Council, see Fiona McGaughey, From gatekeepers to GONGOs: A taxonomy of Non-Governmental Organisations engaging with United Nations buman rights mechanisms, 36 NETH. Q. HUM. RTS. 111, 111-32 (Apr. 16, 2018).

124. Eric Tistounet, Ten Years On: From a Short Play with Intermissions to Opera Without Pause, INT'L SERV. HuM. RTS. (June 4, 2016), https://www.ishr.ch/news/ten-yearsshort-play-intermissions-opera-without- pause.

125. Economic and Social Council Res. 1996/31, ๆ 1 29, $41-44$ (July 25, 1996).

126. See, e.g., The Backlash Against Civil Society Access and Participation at the United Nations, INT'L SERV. HuM. RTS. 2, 4-5 (May 30, 2018), https://www.ishr.ch/news/newreport-backlash-against-civil- society-access-and-participation-united-nations (last visited July 22, 2019) (noting examples where individual countries black listed NGOs for "ties to terrorism" with offering any evidence); NGO Committee: Politics Front and Centre as Human Rights NGOs Get Deferred Again, InT'L SERV. Hum. RTS. (2018), https://www.ishr.ch/news/ngo-committee-politics-front-and-centre-human-rightsngos-get-deferred-again ("Only 7\% of deferred applications from human rights organisations were recommended for accreditation, compared to $23 \%$ of development NGOs.”). 
clear: effective NGO engagement enhances the relevance, efficiency and impact of UN human rights mechanisms and contributes constructively to states' understanding and implementation of their international human rights obligations. ${ }^{127}$ Skilled and determined advocacy efforts by NGOs can make a key difference between success and failure in prompting Council action on a matter, as seen for example in the case study on SOGI rights at the Council discussed below. In a promising sign, the participation of NGOs continues to increase, in particular NGOs from the developing world. ${ }^{128}$

\section{WHY DOES THE COUNCIL FUNCTION SUB- OPTIMALLY?}

As is clear from the above overview of the Council, it is not functioning as effectively as it could. It is beset by politicization, which affects the quality and credibility of its output, and stymies the efforts of mandate-holders and civil society to uphold human rights standards. In this Part, we examine the reasons why this is so.

\section{A. MEMBERShip}

Membership of the Commission by States with terrible human rights records - and a desire to undermine the effectiveness of the Commission itself-was a key factor in that institution's downfall. When the Council was being established, there were hotly contested debates over membership criteria. While the stronger proposals were rejected, ${ }^{129}$ a number of 'soft' measures designed to protect the integrity of the Council's membership were adopted as explained above. There is some evidence that these modest proposals have served to keep some of the worst abusers off the Council. ${ }^{130}$

127. Ben Schokman \& Phil Lynch, Effective NGO engagement with the Universal Periodic Review, in Human Rights and the Universal Periodic Review: Rituals and RiTUALISM 126-46 (Hilary Charlesworth \& Emma Larking eds., 2015).

128. See Laura K. Landolt \& Byungwon Woo, NGOs Invite Attention: From the United Nations Commission on Human Rights to the Human Rights Council, 16 J. HUM. RTS. 407, 409$10,415,417-18$ (2017) (summarizing a recent study indicating a sharp increase in NGO participation and its important effects on the HRC).

129. See, e.g., Alston, Reconceiving the U.N. Human Rights Regime, supra note 25, at 193 ("In 2004, the US suggested that the Commission should avoid becoming 'a protected sanctuary for human rights violators who aim to pervert and distort its work' by insisting that only 'real democracies' should enjoy the privilege of membership.").

130. Mallory, supra note 22, at 3. 
However, serious human rights abusers continue to gain seats on the Council, so reform of the membership continues to be a common theme amongst proposals for change. For example, US Secretary of State Mike Pompeo stated the following in his statement on the US withdrawal from the Council:

Its membership includes authoritarian governments with unambiguous and abhorrent human rights records, such as China, Cuba, and Venezuela.

There is no fair or competitive election process, and countries have colluded with one another to undermine the current method of selecting members. ${ }^{131}$

The then-US Ambassador to the UN, Nikki Haley, stated:

One of our central goals was to prevent the world's worst human rights abusers from gaining Human Rights Council membership. What happened? In the past year, the Democratic Republic of Congo was elected as a member. The DRC is widely known to have one of the worst human rights records in the world. Even as it was being elected to membership in the Human Rights Council, mass graves continued to be discovered in the Congo.

Another of our goals was to stop the council from protecting the world's worst human rights abusers. What happened? The council would not even have a meeting on the human rights conditions in Venezuela. Why? Because Venezuela is a member of the Human Rights Council, as is Cuba, as is China. ${ }^{132}$

Haley here reflects the constant critique of the Council as "dictatorfriendly" and "pro-rogue regimes." 133 Yet a number of comments may

131. Michael Pompeo \& Nikki Haley, Remarks on the U.N. Human Rights Council, U.S. DEP'T OF STATE (June 19, 2018).

132. Pompeo \& Haley, supra note 131.

133. See, e.g., Rosa Freedman, How Rights Violators Keep the U.N. Human Rights Council Focused on Israel, THE CONVERSATION (July 7, 2015, 10:25 AM), http://theconversation.com/how-rights-violators-keep-the-un-human-rights-councilfocused-on-israel-44319 ("Israel is an occupying power - as are China, Turkey, and Morocco, among others, all of whom ought to be scrutinised."); Jon Sharman, U.K. Puts U.N. Human Rights Council 'On Notice' Over 'Anti-Israel Bias', THE InDEPENDENT (Mar. 25, 2017), http://www.independent.co.uk/news/world/middle-east/uk-un-humanrights- council-on-notice-israel-bias-palestinian-settlement-a7649171.html (noting human rights concerns in China, Egypt, \& Saudi Arabia); Brett D. Schaefer, U.S. Withdrawal From the U.N. Human Rights Council is the Right Decision, THE HeRITAge 
be made in response. First, it cannot be right that Venezuela was kept off the Council's agenda due to the presence of itself, and China and Cuba, on the Council. They are only three votes: other Members therefore helped drive that decision. Secondly, Haley does not mention any of the many States on the Council in with relatively "good" human rights records such as Australia, Chile or Japan. Finally, she names no State that is a close US ally, hence Saudi Arabia and Iraq are not mentioned, despite objectively appalling human rights records.

The obsession with the identity of those elected to the Council leads us to a key question: how bad, in fact, is the Council's membership? Is it disproportionately populated by authoritarian and human rights abusing regimes?

The relative human rights performance of Council members will vary, as one third of its members are elected each year. It is difficult to rate, rank or measure a Member's human rights performance in the absence of globally endorsed criteria. Reputable sources, such as the Concluding Observations of UN treaty bodies, are not written in such a way as to easily compare countries so as to facilitate a ranking of States.

Nevertheless, we have resorted to one such index, simply to convey some sort of picture of the human rights records of Council members, and therefore of the Council as a whole. The Freedom in the World index, compiled annually by the NGO Freedom House, rates States as "free," "partly free," or "not free," according to certain political rights and civil liberties criteria. ${ }^{134}$ An analysis of the 2018 Council membership reveals that $69 \%$ are rated "free" or "partly free," with $44 \%$ rated

FOUND. (June 21, 2018), https://www.heritage.org/global-politics/commentary/uswithdrawal-the-un-human-rights-council-the-right-decision (emphasizing the HRC's inability to condemn human right violations in influential countries like China, Cuba, Russia, Saudi Arabia, \& Zimbabwe despite heavy bias against Israel); Gabriel Sassoon, Ban Tyrants From Sitting On U.N. Rights Body, FORBES: CAPITAL Flows (July 24, 2014), https://www.forbes.com/sites/realspin/2014/07/24/ban-tyrants-from-sitting-onun-rights-body/ (arguing the HRC's agenda is driven by human rights abusers who frequently escape condemnation); David May, How to Fix the U.N.'s Anti-Israel Club of Dictators, THE HILL (Mar. 31, 2018), https://thehill.com/opinion/international/381061-how-to-fix-the-uns-anti-israelclub-of-dictators (recognizing that Israel was the target of censure in five separate resolutions, while North Korea, Iran, and Syria have only received four).

134. Democracy in Retreat: Freedom in the World 2019, FreEDOM House (2019), https://freedomhouse.org/report/freedom-world/freedom-world-2019/democracyin-retreat. 
"free." 135 29\% are rated "not free." The 2019 membership follows a similar pattern: $50 \%$ of member states are ranked "free," $21 \%$ "partly free," and 29\% "not free." A brief look at previous years reveals that, in any given year, "free" States outweigh "not free" States.

The Freedom of the World index has significant limitations, such as its emphasis on civil and political rights to the exclusion of economic and social rights. However, our brief analysis of its rankings refutes the contention that the Council is overpopulated with grave human rights abusers. In fact, the proportion of "free," "partly free," and "not free" States mirrors the global preponderance of each category. ${ }^{136}$

Despite its problems, the Council is a body which represents the world of today. The causes of its dysfunction are more complex than the mere presence of States with terrible human rights records. Uncooperative behavior within the Council comes from states with and without 'good' human rights records. While some reform of the membership criteria could be welcome, we argue that the battle for universal human rights observance will not be won by adopting an "us and them" mentality, which a priori excludes significant numbers of countries in the world from "the human rights club." Such a solution is more likely to lead to balkanized human rights discussions, and possible competing intergovernmental institutions inside the UN. We believe that the Council must remain a forum where non like-minded States, and civil society, can talk to each other and occasionally cross divides to make important human rights decisions. ${ }^{137}$

135. See Iceland Replaces U.S. at U.N. Human Rights Council, ICELAND MONITOR: POL. \& SOC'Y July $\quad$ 13, 2018), https://icelandmonitor.mbl.is/news/politics_and_society/2018/07/13/iceland_repla ces_us_at_un_human_rights_council/ (recognizing that Iceland has replaced the US on the Council - as both are ranked "free" they have been counted as one member for the purposes of this analysis).

136. See Michael J. Abramowitz, Freedom in the World 2018: Democracy in Crisis, FREEDOM HOUSE 2 https://freedomhouse.org/sites/default/files/01042018_FINAL_PressRelease_FIW 2018.pdf (concluding 45\% of qualifying countries are "free," $30 \%$ are "partly free" and $25 \%$ are "not free").

137. See Schrijver, supra note 1, at 822 (characterizing the non-participation of the US under the Bush administration in the early days of the HRC as a "serious handicap"). 


\section{B. Politicization, Selectivity, And Double Standards}

A key criticism of the Council is its "selectivity," whereby "one internationally responsible actor is singled out for condemnation, whilst others escape censure for similar abuses." 138 Selectivity is normally intertwined with politicization, that is, the introduction of unrelated controversial issues into the Council by States in order to further their political interests. ${ }^{139}$ As an intergovernmental body, the Council can be expected to be political. However, extreme politicization and selectivity undermine the Council's credibility and effectiveness. ${ }^{140}$

These issues are not new. In 2005, then-Secretary General Kofi Annan observed in relation to the Council's predecessor:

The Commission's ability to perform its tasks has been ... undermined by the politicization of its sessions and the selectivity of its work. We have reached a point at which the Commission's declining credibility has cast a shadow on the reputation of the United Nations system as a whole. ${ }^{141}$

Despite widespread hope that the Council would avoid the Commission's mistakes, many States and commentators have expressed dismay at the Council's politicization. States routinely direct excessive scrutiny at some countries, altogether ignore other abusers, and shield yet others from action. ${ }^{142}$ While States from all regions and persuasions engage in politicized behavior, those who are members of the NonAligned Movement and the Organisation of Islamic Cooperation (OIC) have been most frequently criticized for adopting these tactics. ${ }^{143}$

138. Heinze, supra note 7 , at 7.

139. See Gene M. Lyons et al., The "Politicization" Issue in the U.N. Specialized Agencies, 32 PROC. ACAD. POL. SCI. 81, 89-90 (1977) (analyzing the concept of "politicization").

140. Rosa Freedman \& Ruth Houghton, Two Steps Forward, One Step Back: Politicisation of the Human Rights Council, 17 HuM. RTS. L. REV. 753, 754 (2017).

141. U.N. Secretary-General, Secretary-General's Address to the Commission on Human Rights (Apr. 7, 2005), https://www.un.org/sg/en/content/sg/statement/2005-04-07/secretary-generalsaddress-commission-human-rights.

142. See, e.g., Rosa Freedman, The United Nations Human Rights Council: A CRITIQUE AND EARLY ASSESSMENT 173-88 (2013).

143. See Yaniv Roznai \& Ido Tzang, The United Nations Human Rights Council and Israel: Sour Old Wine in a New Bottle, 5 Hum. RTS. GLOB. L. REV. 25, 51-52 (2013) (arguing the decrease in representation of Western countries combined with the increase in representation of African and Asian countries has resulted in the OIC becoming more influential, and utilizing that influence to set the agenda). 
These tactics are adopted for a range of reasons. At a pragmatic level, by focusing the Council's limited time and resources disproportionately onto a particular State, other States escape scrutiny. Defending an ally can also provide "insurance" in case the defender (the State deploying the argument) should one day itself come under fire over human rights. ${ }^{144}$ More prosaically, politicization has likely become part of the embedded institutional culture of the Council. ${ }^{145}$

For developing States, politicization may also serve an important role in their negotiations with more powerful States. Lyons et al. contend that politicization can function as a form of protest. In the constant struggle to place issues of concern for the Global South on the global agenda, protest can be a way for Southern states to amplify their voices. Seen from this perspective, "politicization" could be viewed as an attempt by frustrated and relatively powerless nations to increase their bargaining power. ${ }^{146}$

Politicization of the Council is not the preserve of non-Western countries. The Council has barely noted serious human rights violations in Afghanistan, Iraq and Saudi Arabia, partly because Western States shield themselves and their allies from scrutiny. ${ }^{147}$ As discussed below, while the US has rightly pointed to bias against Israel within the Council, it has continued to offer reflexive support to its ally despite Israel's perpetration of serious human rights abuses.

Western States have also, at times, refused to engage cooperatively with special procedures mandate holders. ${ }^{148}$ For example, in response

144. See FREEDMAN, supra note 142, at 139.

145. See Meghan Abraham, A NeW Chapter For Human Rights: A HANDBOOK ON ISSUES OF TRANSITION FROM THE COMMISSION ON HUMAN RigHTS TO THE HUMAN Rights COUNCIL 15 (Eléonore Dziurzynski ed., 2006) (“The powers and functions of the Council are only a part of the reform process, the largest determinant of which will be the willingness of States to change their own culture of functioning and to empower the Council to act in accordance with its mandate.").

146. Lyons et al., supra note 139, at 87 (we note that many, though not all, developing States have grown in power since Lyons et al. wrote).

147. See Philippe Dam, Ten Lessons from 30 Sessions: Improving the Human Rights Council, INT'L SERV. HUM. RTS. (May 26, 2016), http://www.ishr.ch/news/ten-lessons-30sessions-improving-human-rights-council ("Western States' paralysis has hampered efforts to address important human rights crises, including on Bahrain, Azerbaijan, Egypt and in response to the crimes committed by the Saudi-led coalition in Yemen.”).

148. See Rosa Freedman \& François Crépeau, Supporting or Resisting? The Relationship between Global North States and Special Procedures, in U.N. SPECIAL PROCEDURES SYSTEM 
to the 2015 report of the UN Special Rapporteur on Torture and Other Cruel, Inhuman or Degrading Treatment or Punishment, thenAustralian Prime Minister Tony Abbott declared that Australians were "sick of being lectured to by the United Nations." "149 Canada rejected the recommendations of the Special Rapporteur on Indigenous Rights in 2015. ${ }^{150}$ In 2016, the United Kingdom rejected criticism regarding arbitrary detention, and was openly critical of the Special Rapporteurs on Adequate Housing and Violence Against Women. ${ }^{151}$

These objections are typical of an assumption by WEOG States of superior human rights records as if they should be above scrutiny. For example, in responding to the 2018 report of the Special Rapporteur on extreme poverty which scrutinized the US, Ambassador Haley suggested that "the special rapporteur wasted the UN's time and resources, deflecting attention from the world's worst human rights abusers and focusing instead on the wealthiest and

411, 412, 417-18 (Aoife Nolan et al. eds., 2017) (emphasizing that the broader the mandate, the less likely western states are to support it).

149. Lisa Cox, Tony Abbott: Australians "Sick of Being Lectured To" by United Nations, After Report Finds Anti-Torture Breach, THE SYDNEY MORNING HERALD (Mar. 9, 2015, 3:14 AM), https://www.smh.com.au/politics/federal/tony-abbott-australians-sick-ofbeing-lectured-to-by-united-nations-after-report-finds antitorture breach-20150309$13 z 3 j 0 . h t m l$.

150. Mike Blanchfield, Canada Rejects U.N. Call for Review of Violence Against Aboriginal Women, THE GLOBE \& MAIL (Sept. 19, 2013), https://www.theglobeandmail.com/news/national/canada-to-reject-un-panels-callfor- review-of-violence-on-aboriginal-women/article14406434/; James Anaya (Special Rapporteur), Rep. on the rights of indigenous people, The situation of indigenous peoples in Canada, U.N. Doc. A/HRC/27/52/Add.2 (July 4, 2014); U.N. Off. of the High Comm'r for Hum. Rts., Canada must address root causes of extreme violence and discrimination against indigenous women - Rights experts (Feb. 1, 2016), https://www.ohchr.org/en/NewsEvents/Pages/DisplayNews.aspx?NewsID=17004 \&LangID $=\mathrm{E}$.

151. U.N.A.-U.K. Concerned by Dismissive Comments About U.N. Human Rights Mechanism, U.N.A.-U.K. (Feb. 16, 2016), https://www.una.org.uk/news/una-ukconcerned-dimissive-comments-about-un-human-rights-mechanism; Amelia Gentleman \& Patrick Butler, Ministers Savage U.N. Report Calling for Abolition of U.K.'s Bedroom Tax, THE GUARDIAN (Feb. 3, 2014), https://www.theguardian.com/society/2014/feb/03/ministers-savage-un-reportabolition-bedroom-tax; Laura Bates, Rashida Manjoo is Right about British Sexism - Even If it is Worse Elsewhere, THE GUARDIAN (Apr. 17, 2014), https://www.theguardian.com/lifeandstyle/womens-blog/2014/apr/17/rashidamanjoo-british-sexism-female-suffering. 
freest country in the world." ${ }^{152}$ It bears emphasizing that the Special Rapporteur found comparably high rate of poverty in the US, and indications that extreme poverty is increasing. His conclusions were based on sound evidence and data. ${ }^{153}$

In conclusion on this point, all States engage in politicized and selective behavior on the Council, though some are worse in this respect than others. Decisions are often made and votes influenced by a State's political interests rather than its interests in promoting global human rights.

\section{BLOC BEHAVIOR}

Each State on the Council is elected as a member of a particular geographic bloc. These blocs influence (to varying degrees) how their members behave and vote. Aside from the official UN groupings, other blocs and alliances crisscross the UN regions, such as the Group of 77, the Non Aligned Movement, the Like Minded Group, and the European Union.

States often vote in blocs, make repeat statements and statements of allegiance, as well as make wholly irrelevant statements in order to protect bloc allies or attack bloc enemies. ${ }^{154}$ Abebe contended in 2009 that the African Group had "deftly manipulated" the "sub-culture" of factionalism and group alliance at the Council to create the Council it wants-one in which independent oversight (from civil society and independent experts) is limited, and country-specific condemnation is eschewed in favor of a cooperative and consensual approach. ${ }^{155}$

152. Ed Pilkington, Nikeki Haley Attacks Damning U.N. Report on U.S. Poverty Under Trump, THE GUARDIAN (June 21, 2018, 4:39 PM) https://www.theguardian.com/world/2018/jun/21/nikki-haley-un-poverty-reportmisleading-politically-motivated.

153. See Philip Alston (Special Rapporteur), Rep. on extreme poverty and human rights on his mission to the United States of America, q1 1-3, U.N. Doc. A/HRC/38/33/Add.1 (May 4, 2018) (noting the Special Rapporteur received more than 40 detailed written submissions in advance of his visit and met with government officials at all levels, in addition to residents, people living in poverty, and academics). In 2019, the UK was similarly displeased with the same Special Rapporteur's scathing report on extreme poverty in that country.

154. See FREEDMAN, supra note 142, at 201 (discussing repetitive statements made by members of the African Group and the OIC).

155. Allehone Mulugeta Abebe, Of Shaming and Bargaining: African States and the Universal Periodic Review of the United Nations Human Rights Council, 9 HUM. RTS. L. REV. 1, 3 (2009). 
Furthermore, many developing States lack significant political and economic clout, so they have few levers to pull to protect themselves from current or future criticism beyond bloc solidarity and a track record of support for state sovereignty. Idriss Jazaïry suggests that a failure to work together as a bloc would "spell disaster for weaker countries." ${ }^{156}$

The OIC contains members which straddle the two most numerous UN blocs, Asia and Africa. Hence, it can push for resolutions which have a good chance of gaining the support of a significant percentage of the Council. ${ }^{157}$ The OIC has not been shy in wielding arguably disproportionate influence. In contrast, the European Union has not been so savvy in pushing for initiatives that it would like to see adopted. In part, this is because it can spend a long time coming to a common position, now a requirement under EU treaties. ${ }^{158}$

The existence and behavior of blocs may be a key source of the Council's dysfunction. However, the influence of blocs is less straightforward than is commonly thought. Hug and Lukács have found that voting which appears to be bloc driven can be interest driven. ${ }^{159}$ The influence of bloc pressures - as opposed to the alignment of interests and convictions - can be hard to untangle.

\section{THE SOVEREIGNTY DIVIDE}

Since the Second World War, international human rights law has made

156. See generally Idriss Jazairy, The Role of Regional Groups and Coordinators: A Case Study - The African Group, in THE First 365 Days OF THE United NATIONS Human Rights COUNCIL 129 (Lars Müller ed., 2007) (we add that Mr Jazaïry undoubtedly possesses insight into the matter, as he is the current Special Rapporteur on unilateral coercive measures and was formerly the Algerian Permanent Representative to the United Nations in Geneva).

157. See, e.g., FreEdMAN, supra note 142, at 126.

158. See, e.g., Richard Gowan \& Franziska Brantner, The E.U. and Human Rights at the U.N.: 2011 Review, Euro. COUnCIL FOrEIGN RELATIOns 1-2 (Sept. 2011), https://www.ecfr.eu/page/-/ECFR39_UN_UPDATE_2011_MEMO_AW.pdf (observing that the EU's "voting coincidence score" - a measure of its overall support from other states for EU positions in human rights votes in the General Assembly has stayed level at $44 \%$, more than $10 \%$ behind both China's \& Russia's scores); FREEDMAN, supra note 142, at 205 (highlighting the EU's "internal difficulties in adopting a common position and the inability of members to deviate from that position within the Council or to negotiate and compromise with other groups or blocs.").

159. Simon Hug \& Richard Lukács, Preferences or Blocs? Voting in the United Nations Human Rights Council, 9 REV. INT'L ORG. 83, 84 (2014). 
significant incursions into the traditional zones of State sovereignty. In particular, human rights abuses are no longer a State's "own business." It is legitimate for international organizations with human rights mandates, or individual States, to raise human rights concerns and to strongly criticize a State's human rights record.

Nonetheless, many States, particularly developing States, rely on arguments based on of sovereignty to push back against country-specific action by the Council. ${ }^{160} \mathrm{~A}$ wide range of developing States-including most of the African Group, and middle powers such as India-resist country-specific special sessions as a matter of course. ${ }^{161}$ For example, India abstained on resolutions relating to the appalling situation in Syria on the basis that "constructive dialogue is more productive than "finger-pointing and intrusive monitoring." 162 Fisher argues that by prioritizing sovereignty in this way, States are "rewarding noncooperation, and clearly breaching the Council's mandate to address gross and systematic violations." 163

Where scrutiny is unavoidable, many developing States prefer that it occurs under the Council's agenda item 10 (technical assistance and capacity-building) rather than agenda item 4 (human rights situations that require the Council's attention). Not only does agenda item 10 avoid 'naming and shaming' the offending states, it also leaves the relevant government in control of the process and implies that the government is committed to improving its rights record, irrespective of evidence to the contrary.

Numerous reasons account for this phenomenon. Many developing States have serious human rights problems, so deployment of the state sovereignty argument is a strategy to ward

160. See Jean-Philippe Thérien \& Philippe Joly, "All Human Rights for All”: The United Nations and Human Rights in the Post-Cold War Era, 36 HuM. RTS. Q. 373, 395 (2014).

161. See Eduard Jordaan, Rising Powers and Human Rights: The India-Brazil-South Africa Dialogue Forum at the UN Human Rights Council, 14 J. Hum. RTS. 463, $465-66$ (2015). See, e.g., Arvind Narrain, India's Role in the Human Rights Council: Is There a Constitutional Vision in its Foreign Policy?, 57 INDIAN J. INT’L L. 87, 98-99 (2017) (emphasizing that India tends to abdicate any leadership role on human rights even in the case of egregious violations, such as the conflict in Syria).

162. See Jordaan, supra note 161, at 471.

163. John Fisher, Potential Unfulfilled: Strengthening the Council's Approach to Country Situations, INT'L SERV. HUM. RTS. (May 30, 2016), https://www.ishr.ch/news/potential-unfulfilled-strengthening-councils- approachcountry-situations. 
off unpleasant criticism. Furthermore, as noted above, weaker States (which make up the majority of the UN and the Council) may want the insurance of a known commitment to state sovereignty in case they should find themselves in the firing line in the future.

Many developing States are former colonies that are very protective of their relatively recent independence. They are or feel more vulnerable to a possible loss or weakening of their sovereignty than longer established States. Stanton argues that "it is well-known that the practice of intervention has diverged from international law with respect to 'less civilized,' 'non-Western,' 'developing' states, leaving intervention linked with imperialism and colonialism in historical memory." 164 More pragmatically, many former colonies continue to face significant challenges to their sovereignty, either from separatist minority groups or from breakdowns in peace, security and public order. ${ }^{165}$

More generally, some commentators from the developing world see the power dynamics of colonialism replicated in the UN, and the Council specifically. Adebajo has described African States' positions in the UN one in which in which they wield little influence, while receiving considerable criticism - as 'global apartheid.' He suggests that:

[T] he paradox of the [UN] is that while it embodies ideals of justice and equality, the power politics embedded in its structures... often mean that the powerful Brabmins of international society (the 'Great Powers') can manipulate the system to the disadvantage of the wretched 'untouchables'). ${ }^{166}$

In reviewing the UN at the end of last century, Ali Mazrui declared that:

[T] he UN deserves two cheers for trying to contribute to the racial, gender, ecological, and equity revolutions of the twentieth century ... But the United Nations gets no cheers at all for acting as an instrument of

164. Kimberly Stanton, Pitfalls of Intervention: Sovereignty as a Foundation for Human Rights, 16 HARV. INT'L REV. 14, 16 (1993).

165. See generally Francis M. Deng, The Evolution of the Idea of 'Sovereignty as Responsibility', in Global APARTHEID TO GLOBAL VILLAGE: AFRICA AND THE UNITED NATIONS 191 (Adekeye Adebajo ed., 2009) (discussing the implications for sovereignty of these conditions).

166. Adekeye Adebajo, Ending Global Apartheid: Africa and the United Nations, in Global Apartheid to Global Village: Africa AND the United NATIONS 3 (Adekeye Adebajo ed., 2009). 
counterrevolution in the furtherance of Western cultural hegemony. Better luck in the twenty-first century. ${ }^{167}$

Of course, political intervention by the West did not cease with the end of colonialism, with covert US intervention across much of the world since the 1950s and recent overt interventions by Western powers in Iraq, Kosovo, Libya and Mali. The US regularly deploys unmanned drones to kill suspected terrorists in other States. Political intervention is not limited to the West-for example note Saudi Arabia's intervention in Yemen and that of Russia in the Ukraine. However, Western States are those most likely to engage in and agitate for military intervention in other States, for example via activation of a "responsibility to protect." 168

WEOG States also continue to exercise considerable power over the developing world through economic interventions initiated by bodies in which they have the greatest say, the International Monetary Fund and the World Bank. ${ }^{169}$ Western developed States also have the better end of

167. Ali A. Mazrui, The New Dynamics of Security: The United Nations and Africa, 13 WORLD POL'Y J. 37, 42 (1996).

168. See Andrew Garwood-Gowers, The Responsibility to Protect and the Arab Spring: Libya as the Exception, Syria as the Norm? 36 U.N.S.W. L. J. 594, 597-98 (2013) (explaining the controversy that R2P has generated amongst states); Elizabeth O'Shea, Responsibility to Protect (R2P) in Libya: Ghosts of the Past Haunting the Future, 1 INT'L HUM. RTS. L. REV. 173, 185 (2012) ("The interests of the NATO countries have defined the priorities of the intervention in Libya.").

169. See, e.g., Daniela Magalhães Prates, Rise of the Global South and Descent of the North? Exploration of the Rise of the Global South and Its Impact on International Financial Architecture, BRETTONWOODS PROJECT (Sept. 2015), https://www.brettonwoodsproject.org/2016/03/rise-of-the-global-south-anddescent-of-descent-of-the-north/ (discussing the US Congress' block of the IMF's 2010 governance reforms, making Brazil, China, India, and Russia among the top 10 IMF shareholders); Michel Chossudovsky, The Globalization of PoverTy AND THE NEW WORLD ORDER 24 (2d ed. 2003) (explaining the role of the WTO under the umbrella of global institutions, alongside the IMF and World Bank); Joseph E. Stiglitz, Democratizing the International Monetary Fund and the World Bank: Governance and Accountability, 16 GOVERNANCE 111, 113-16 (2003) (debating whether the IMF intentionally failed in stabilizing East Asia in order to pursue other objectives); Mark J. Wolff, Failure of the International Monetary Fund \& World Bank to Achieve Integral Development: A Critical Historical Assessment of Bretton Woods Institutions Policies, Structures \& Governance, 41 SYRACUSE J. INT’L L. \& COM. 71, $94-96$ (2013) (quoting JOSEPH E. STiglitz, Globalization and ITs Discontents, 16 (2003)) ("The Keynesian orientation of the IMF, which emphasized market failures and the role for government in job creation, was replaced by the free market mantra of the 1980' s, as part of a new "Washington Consensus"- a consensus between the IMF, the World Bank, and the U.S. Treasury about the "right" policies for developing countries-that signaled a radically 
the lopsided global trading obligations devised under the auspices of the World Trade Organisation, ${ }^{170}$ which gives them even more leverage over the economies of poorer States.

Therefore, the majority of the Council, which reflects the majority of the UN itself and the majority of the world's population, is made up of developing States that are resistant to strong condemnatory resolutions and interference in States on human rights grounds. Those who are most in favor of strong resolutions and actions are the developed high-income States. It does not help the atmospherics within the Council that the most interventionist members are the former colonizers and sites of major economic and military power, ${ }^{171}$ whereas those most suspicious of intervention are generally the former colonies and the most economically vulnerable.

The sovereignty issue is further muddied by its occasional use by developed States when the spotlight is turned on their own human rights records. For example, Secretary Pompeo stated, with regard to the US withdrawal from the Council:

... when organizations undermine our national interests and our allies, we will not be complicit. When they seek to infringe on our national sovereignty, we will not be silent. The United States-which leads the world in humanitarian assistance, and whose service members have sacrificed life and limb to free millions from oppression and tyranny-will not take lectures from hypocritical bodies and institution as Americans selflessly give their blood and treasure to help the defenseless. ${ }^{172}$

Indeed, the US statement is steeped in irony, as it fiercely guards its own sovereignty whilst referring to its own incursions into the sovereignty of other States.

At its heart, there is a long-term rift between the Global North (or

different approach to economic development and stabilization.").

170. Pascal Lamy, The Geneva Consensus: Making Trade Work For All 3 (Cambridge Univ. Press 2013).

171. The long period of Western economic dominance may be starting to wane with the rise of China, Brazil, India, and Russia, as well as the meandering economies of Europe and the US. See generally Dan Steinbock, The Global Economic Balance of Power is Shifting, WORLD ECON. F. (Sept. 20, 2017), https://www.weforum.org/agenda/2017/09/the-global-economic-balance-of-poweris-shifting (predicting that by the early 2030s, the BRICs' combined economic power will surpass that of the major advanced nations).

172. Pompeo \& Haley, supra note 131. 
"Western States") and the Global South that continues to permeate the $\mathrm{UN}$, even if positions are probably more nuanced than in the past. The Human Rights Council, and before it the Commission, is a site where States continue to highlight or reflect broader historical, economic and developmental grievances and injustices. These concerns are not irrelevant to human rights, but they can distort the Council's intended focus on human rights concerns.

\section{E. A STUdy In Dysfunction: THE Human Rights COUNCIL AND ISRAEL}

Although politicization and selectivity are widespread at the Council, the focus on Israel's actions in the Occupied Palestinian Territory is the most extreme and enduring example of these phenomena. While an outlier, the treatment of Israel provides an illustration of some of the underlying dynamics which threaten the functioning of the Council generally, in particular the North/South divide, the historical legacy of the struggle against oppression and colonialism, and reflexive bloc behavior.

Bias against Israel was widely acknowledged as a feature of the Commission ${ }^{173}$ and continues in the Council. Israel is the only country which is the subject of its own standing agenda item. ${ }^{174}$ It has been the subject of more special sessions than any other State. ${ }^{175}$ Its special procedure stands in perpetuity until the Occupation is over, and the mandate-holder can only investigate its actions rather than those of

173. See Roznai \& Tzang, supra note 143, at 53-55 ('[T] he HRC's selective application of human rights review is discriminatory and it violates the universal nature of human rights."); Jack Donnelly, Human Rights at the United Nations 1955-85: The Question of Bias, 32 INT'L STUD. Q. 275, 290-91 (1988) (highlighting the continued condemnation of Israel for human rights violations beyond that of other occupied nations); Ron Wheeler, The United Nations Commission on Human Rights, 1982-1997: A Study of "Targeted" Resolutions, 32 CAN. J. POL. SCI. 75, 98 (1999) (observing that states such as Brazil, China, Greece, Mexico, Saudi Arabia, Syria, and Turkey avoid being targeted by the Commission despite very public human rights violations; yet, resolutions are consistently passed condemning Israel); Henning Boekle, Western States, the U.N. Commission on Human Rights, and the '1235 Procedure': The 'Question of Bias' Revisited, 13 NETH. Q. HUM. RTS. 367, 382-83 (1995) (recognizing the US's continued opposition to HRC criticisms of Israel).

174. See H.R.C. Res. 5/1, supra note 55 ("Human rights violations and implications of the Israeli occupation of Palestine and other occupied Arab territories").

175. See Special Sessions, supra note 63 (as of writing, the Occupied Territories have been the subject of eight special sessions). 
the Palestinians. The many (many) resolutions against Israel are characterized by extraordinarily strong condemnatory language, while abusive actions by the Palestinian authorities and Hamas are largely ignored.

The Israel bias is the main grievance of some of the Council's strongest critics. When announcing the US' withdrawal from the Council, Secretary of State Pompeo described its bias against Israel as "unconscionable," and Ambassador Haley described its "disproportionate focus and unending hostility towards Israel" as "clear proof that the Council is motivated by political bias, not by human rights." ${ }^{176}$

Why is the Council biased against Israel? Certainly, Israel commits serious human rights abuses which are worthy of Council attention and condemnation. Settlements, ${ }^{177}$ forced evictions of Palestinians, ${ }^{178}$ war crimes, ${ }^{179}$ the Gaza blockade, ${ }^{180}$ targeted and other killings by the Israel Defense Forces, ${ }^{181}$ and, most fundamentally, ongoing occupation of over

176. Pompeo \& Haley, supra note 131.

177. Rep. of the Secretary-General, Israeli settlements in the Occupied Palestinian Territory, including East Jerusalem, and in the Occupied Syrian Golan, $\boldsymbol{\uparrow} \uparrow 1,5$, U.N. Doc A/HRC/28/44 (Mar. 9, 2015); U.N. Hum. Rts. Council, Rep. of the independent international fact-finding mission to investigate the implications of the Israeli settlements on the civil, political, economic, social and cultural rights of the Palestinian people throughout the Occupied Palestinian Territory, including East Jerusalem, था 100-11, U.N. Doc A/HRC/22/63 (Feb. 7, 2013); The bumanitarian impact on Palestinians of Israeli settlements and other infrastructure in the West Bank, U.N. OFF. FOR THE COORDINATION HumANITARIAN AFF. (July 30, 2007), https://www.ochaopt.org/content/humanitarian-impact-palestinians-israelisettlements-and-other-infrastructure-west-bank (last visited Sept. 8, 2019).

178. See, e.g., icahduk, Demolition and Displacement Report - May 2019, ISRAELI COMM. Against House Demolitions: News (June 3, 2019), https://icahd.org/2019/06/03/demolition-and-displacement-report-may-2019/ (creating a timeline of Israel's demolitions and occupations in Palestinian Territory); Yael Stone, Fake Justice: The Responsibility Israel's High Court Justices Bear for the Demolition of Palestinian Homes and the Dispossession of Palestinians 7, B’TSELEM (Feb. 2019), https://www.btselem.org/sites/default/files/publications/201902_fake_justice_eng. pdf (explaining Israel retained full control over security matter as well as land-related civil affairs over $60 \%$ of the West Bank).

179. See U.N. Hum. Rts. Council, Human Rights in Palestine and Other Occupied Arab Territories, Rep. of the United Nations Fact-Finding Mission on the Gaza Conflict, at 404-08, U.N. Doc A/HRC/12/48 (Sept. 25, 2009) (linking Israel's policies in the Occupied Palestinian Territory with its military operations in Gaza).

180. Id. at 404-08.

181. Sarit Michaeli, Crowd Control: Israel's Use of Crowd Control Weapons in the West Bank, 
fifty years, ${ }^{182}$ rightly generate condemnation. Nevertheless, that does not explain the Council's disproportionate attention to this one country, given the many extreme human rights abuses perpetrated by other States which receive far less scrutiny.

Israel has many enemies amongst UN States. Many OIC members have never accepted Israel's right to exist, believing that it was established illegitimately on Arab (Palestinian) land. Indeed, the OIC was set up in 1969 "to unite Muslim countries" after the 1967 war in which Israel seized the now-occupied territories, ${ }^{183}$ so opposition to Israel has been an article of faith since its inception. These States therefore bring as much diplomatic pressure to bear as is possible on Israel and are often able to mobilize significant bloc support in aid of that goal.

The racial element, whereby the Jewish State of Israel illegally occupies lands populated by Arabs in the Occupied Territories, attracts the ire of developing States, which have historical grievances regarding racial oppression. ${ }^{184}$ Yet other instances of racial oppression fail to attract the same passion, such as that of the Tibetans, the Kurds, the West Papuans, the Tamils or the Chechens.

One difference is that Israel's occupation of the Palestinian Territories is not recognized as legitimate by any other State besides Israel, unlike for example China's sovereignty over Tibet or Indonesia's sovereignty over West Papua. ${ }^{185}$ Indeed, a large number of States have diplomatically recognized the Occupied Territories as the State of Palestine, and the UN General Assembly voted 2012 to accord Palestine non-member

\footnotetext{
B’TSELEM 29-31, $49 \quad$ (Jan. 2013 ), https://www.btselem.org/download/201212_crowd_control_eng.pdf.

182. Israel denies that it continues to occupy Gaza since it withdrew its forces from the territory in 2005. However, it continues to maintain a blockade and exercise control over most of Gaza's land and sea borders, and airspace. See, e.g., Anna Aronheim, Half of Israelis in Favor of Removing the Blockade on Gaza: Study, JERUSALEM POST (June 13, 2019), https://www.jpost.com/printarticle.aspx?id=592266 (finding " $80 \%$ of Israelis think that the economic situation in Gaza is "difficult to severe," while another 61\% agree that the difficult economic situation in Gaza is directly related to the violent conflict between Hamas and Israel").

183. FREEDMAN, supra note 142, at 124.

184. FREEDMAN, supra note 142, at 131-32.

185. This statement is purely concerned with the fact that most States recognize such sovereignty. It is not to say that that position is unassailable.
} 
observer State status. ${ }^{186}$ Hence, developing States do not have to compromise their traditional concerns for sovereignty in order to criticize Israel's actions in the Occupied Territories.

The fact of occupation also allows States to feel safe in attacking Israel without being hypocritical. For example, members of the African Group have defended their support for the special procedure on the Occupied Territories (in the face of in-principle rejection of country-specific mandates) by arguing that they do not consider it to be a country-specific mandate at all, but a thematic issue on occupation. ${ }^{187}$ While human rights abuses are regrettably common, the status of "an occupier" is rare. Indeed, Israel is sometimes seen as a "remnant of colonialism." 188 This also explains why the focus is on Israel's actions in the Occupied Territories, rather than its actions in Israel "proper." However, Israel is not the only occupier. Morocco has long illegally occupied the Western Sahara yet there is comparable global silence on that situation. ${ }^{189}$

Israel is also seen as a surrogate for the West, particularly the US. Given that Israel is almost always defended within the UN by the US, ${ }^{190}$ and is often defended by much of WEOG, "Israel- bashing" has become part of a greater North/South divide in the UN. AntiAmerican States such as Cuba, Venezuela, Ecuador and Russia see Israel as "the US foothold in the Middle East" and use the issue to "attack US hegemony and interference." ${ }^{191}$ Furthermore, bias against Israel can be matched in the Council by biased displays of unwavering support from States such as the US and Australia.

Some defenders of Israel, such as the NGOs UN Watch and Human

186. G.A. Res. 67/19, $\mid 2$ (Dec. 4, 2012).

187. Allehone Mulugeta Abebe, Of Shaming and Bargaining: African States and the Universal Periodic Review of the United Nations Human Rights Council, 9 Hum. Rts. L. Rev. 1, 33 (2009).

188. FREEDMAN, supra note 142, at 131.

189. Kristen Chick, In Remote Western Sahara, Prized Phosphate Drives Controversial Investments, CHRISTIAN SCI. MONITOR (Jan. 24, 2013), https://www.csmonitor.com/World/Africa/2013/0124/In-remote-Western-Saharaprized-phosphate-drives-controversial-investments; U.N. Hum. Rts. Council, Rep. of the Working Group on the Universal Periodic Review, Morocco, If 88, U.N. Doc. A/HRC/21/3 (July 6, 2012); U.N. Secretary-General, Rep. of the Secretary-General on the Situation Concerning Western Sahara, $\uparrow$ 88, U.N. Doc. S/2013/220 (Apr. 8, 2013).

190. FREEDMAN, supra note 142, at 164.

191. FREEDMAN, supra note 142, at 131. 
Rights Voices, argue vehemently that anti-Semitism is at the heart of the Council's bias. ${ }^{192}$ However, Israel's human rights critics globally encompass a vast range of people, ranging from anti-Semites to people of good will. The equation of anti-Israel with anti-Semitism is oversimplistic. As noted above, other significant reasons exist for the Council's condemnation, including the existence of serious human rights abuses.

Regardless of its causes, the Council's bias against Israel is counterproductive. It provides Israel with a ready-made argument to reject criticism, even when it is legitimate, thus providing cover for human rights abuses. Indeed, claims of bias (within and outside the UN) have become a dominant part of the Middle East narrative, detracting from a focus on the actions of the protagonists.

Furthermore, the Council has done little to discourage wrongful actions by the Palestinian authorities against Israel such as the rocket attacks from Gaza, nor has it addressed the very real abuses perpetrated by those authorities against their own people. Nor, for that matter, does the UN focus on the rights of Israelis within Israel.

Bias has facilitated Israel's progressive disillusionment with and disengagement from the UN, culminating in its minimal cooperation with the UPR, and has been a key pretext for the US walkout. It opens the Council up to charges of hypocrisy and selectivity and reduces its credibility. None of these outcomes are useful for those who sincerely wish for improvements in human rights for all in Israel and the Occupied Territories, or for the proper functioning of the Council. If the Council is to survive and thrive, redirecting some of the time and attention placed on Israel towards other grave human rights situations would be a good start.

192. Anne Bayefsky, Trump's Wise to Quit the UN Human Rights Council - It's an Oxymoron Not Worthy of our Respect or Support, FOX NEWS (June 19, 2018), https://www.foxnews.com/opinion/trumps-wise-to-quit-the-un-human-rightscouncil-its-an-oxymoron-not-worthy-of-our-respect-or-support; Anne Bayefsky, Depravity at the U.N. Human Rights Council, JERUSALEM POST (July 24, 2014), https://www.jpost.com/Opinion/Op-Ed-Contributors/Depravity-at-the-UNHuman-Rights-Council-368834. 


\section{IV.FIXING THE COUNCIL}

In this part, we examine the ways in which the Council might realistically improve in fulfilling its role in promoting and protecting human rights across the globe. There are limits to the ability of this political body to become less political-its character as an intergovernmental body would have to change outright in order for that to happen. However, there are strategies or ways in which it can do a much better job. These strategies are exemplified in the following case study, which tracks the Council's engagement with sexual orientation and gender identity (SOGI) rights.

\section{A. CASE STUdy: SEXUAL ORIENTATION AND GENDER IDENTITY RIGHTS AT THE COUNCIL}

Recent decades have seen tremendous advances in the recognition of rights relating to SOGI in many parts of the world, from decriminalization of sexual relations between people of the same sex to the recognition in many nations of marriage equality. Progress on SOGI has similarly been made at the Council. ${ }^{193}$

That progress has, however, been far from linear, and has taken place in the face of significant hostility from some States. In many ways, the evolution of SOGI issues at the Council reflects several of the difficulties and tensions which dominate the institution generally, in particular the North/South divide and claims of moral imperialism, and resistance from the African and OIC groups (and the power of their voting blocs). Despite these obstacles, significant progress has been made on SOGI by the Council in the last decade.

\section{Key SOGI milestones at the HRC}

The first draft resolution on sexual orientation at the Council was tabled by Brazil in 2003. Unfortunately, Brazil was woefully unprepared to champion the resolution. It failed to anticipate the hostile reception from other States, and from domestic actors such as the Catholic Church. It neglected to communicate effectively with civil society, so relevant

193. Dodo Karsay, How Far Has SOGII Advocacy Come at the U.N. and Where is It Heading?, ARC INT'L (2014), https://arc-international.net/wpcontent/uploads/2013/09/How-far-has-SOGII-for-web.pdf. 
organizations were unprepared for the draft resolution. ${ }^{194}$ In 2004, Brazil opted not to resubmit the draft resolution and in 2005, it lapsed. This episode shows how not to move forward in the Council on a contentious issue.

A significant step backwards took place in 2010. In November of that year, the UN General Assembly voted by 79 votes to 70 (with 17 abstentions and 26 absentees) to remove an explicit condemnation of killings on the basis of sexual orientation from a resolution on extrajudicial, summary or arbitrary executions. ${ }^{195}$ The disgraceful implication from this action was that sexual orientation was not an arbitrary ground upon which to execute people. Given that very low point, the progress on SOGI rights since November 2010 has been extraordinary.

In December 2010, the UNGA swiftly reversed its November decision by 93 to 55 with 27 abstentions. ${ }^{196}$ The condemnation of killings based on a person's sexuality was restored after extensive lobbying by the US. ${ }^{197}$ Importantly, local civil society had successfully lobbied States such as South Africa, Colombia and Cuba to change their vote. ${ }^{198}$ As further explored below, this was an important example of States being held to account at home for their voting behavior in the UN. Indeed, in November 2012, 108 States voted for the resolution, and for the first time added a reference to "gender

194. Eduard Jordaan, The Challenges of Adopting Sexual Orientation Resolutions at the UN Human Rights Council, 8 J. HuM. RTS. PRACT. 298, 301 (2016).

195. U.N. General Assembly, Promotion and Protection of Human Rights: Human Rights Questions, Including Alternative approaches for Improving the Effective Enjoyment of Human Rights and Fundamental Freedoms, Rep. of the Third Comm., ๆ 63, U.N. Doc. A/65/456/Add. 2 (Part II) (Dec. 8, 2010); Sarah Joseph, The U.N., Executions, and LGBT Rights, CASTAN CTR. HuM. RTs. L. (Nov. 23, 2010), https://castancentre.com/2010/11/23/the-unexecutions-and-glbt-rights/.

196. U.N. GAOR, 65th Sess., 71st plen. mtg. at 20, U.N. Doc A/65/PV.71 (Dec. 21, 2010).

197. Louis Charbonneau, U.N. Restores Gay Reference to Violence Measure, REUTERS (Dec. 21, 2010), https://www.reuters.com/article/us-un-gaysidUSTRE6BK6UW20101222.

198. Anita Snow, Gay Rights Row Breaks Out Over Amended U.N. Resolution, THE GUARDIAN (Dec. 21, 2010), https://www.theguardian.com/world/2010/dec/21/gayrights-row-un-resolution; Noelle Stout, The Rise of Gay Tolerance in Cuba: The Case of the U.N. Vote, NACLA (Aug. 16, 2011), https://nacla.org/article/rise-gay-tolerance-cubacase-un-vote. 
identity" as a prohibited ground of execution. ${ }^{199} 65$ States abstained and only one State, Iran, voted against the resolution.

A similar struggle over SOGI rights re-emerged in the Council. In mid-2010, several States objected to the focus of the report of the Special Rapporteur on the Right to Health, Anand Grover, on the health consequences of the criminalization of same sex relations for HIV/AIDS transmission. ${ }^{200}$ Bangladesh accused Grover of inventing a new marginalized group, while South Africa disapproved of the focus on LGBTI issues. ${ }^{201}$

Despite its opposition to Grover's report, South Africa emerged as a new leader on SOGI rights a year later. Working closely with Brazil and Norway, and with considerable input from civil society, South Africa worked on a draft resolution which was ultimately adopted by the Council at its seventeenth session in mid-2011. ${ }^{202}$

That document, Resolution 17/19, was relatively weak, expressing "grave concern" over acts of violence and discrimination "in all regions" on the basis of sexual orientation and gender identity. It mandated a report on SOGI-related violence by the UN High Commissioner of Human Rights, and a subsequent panel discussion. Even these modest steps represented a tremendous advance for SOGI rights, and the document is still considered by many SOGI activists to be the most significant single achievement for LGBTI people at the UN. ${ }^{203}$

Almost all of the OIC and the Africa group voted against resolution 17/19, except for South Africa and Mauritius (voting in favor), and Zambia and Burkina Faso (abstaining). This resistance, largely from its own bloc, helps to explain why South Africa's leadership did not endure. ${ }^{204}$ Throughout 2012 and 2013, tensions

199. G.A. Res. 67/168, ๆ 6 (Mar. 15, 2013).

200. Anand Grover (Special Rapporteur on the Right of Everyone to the Enjoyment of the Highest Attainable Standard of Physical and Mental Health), 9ף 4, 11, 13, 15, U.N. Doc A/HRC/14/20 (Apr. 27, 2010).

201. Human Rights Council: Consensus Re-Established on Freedom of Religion and Belief, but Divisive Appointments to Special Procedures Taint 14 $4^{\text {th }}$ Session, HuM. RTS. MONITOR Q. $12-$ 14 (Apr. 2010).

202. H.R.C. Res. 17/19, U.N. Doc. A/HRC/RES/17/19 (June 17, 2011).

203. Dodo Karsay, How Far Has SOGII Advocacy Come at the U.N. and Where is It Heading?, ARC INT'L (2014), https://arc-international.net/wpcontent/uploads/2013/09/How-far-has-SOGII-for-web.pdf.

204. Eduard Jordaan, Foreign Policy Without the Policy? South Africa and Activism on Sexual Orientation at the United Nations, 24 S. AFR. J. INT'L AFF. 79, 91 (2017) [hereinafter 
arose between South Africa and some Western and Latin American states over the pace of developments. South Africa had proposed a series of regional workshops to be held in early 2013, to be followed by a new resolution at the June 2013 Council session. However, South Africa refused to proceed until the African workshop had been held-an event which was repeatedly delayed. South Africa was seeking election to the Council in November 2013 and was worried that its prospects would be damaged by pushing the SOGI cause.

At the March 2014 session, South Africa finally conceded that it would no longer lead on the SOGI issue. ${ }^{205} \mathrm{~A}$ concerted effort from civil society eventually succeeded in convincing Uruguay and Colombia to lead, joined later by Chile and Brazil. These states-known as the LAC 4 led the Council to adopt its second SOGI resolution in 2014. ${ }^{206}$ While the draft resolution met with considerable resistance, particularly from members of the OIC and the African Group, ${ }^{207}$ it was adopted by an absolute majority of the Council, with support from States from all regions, and a substantial increase in the margin of success compared to $2011 .{ }^{208}$

From 2014, the core leadership group expanded to include Argentina, Mexico and Costa Rica. The (renamed) LAC 7 took the lead in proposing a draft resolution in 2016, which included the establishment of a dedicated special procedure on SOGI. The resolution eventually passed with 23 votes for, 18 against, and 6 abstentions. ${ }^{209}$ In September 2016, Mr. Vitit Muntarbhorn was appointed the first UN Independent Expert on violence and discrimination based on sexual orientation and gender identity. In late 2016, the African group proposed amendments in the General Assembly which would have deferred action on the establishment of the mandate and denied it budgetary resources. These

Jordaan, Foreign Policy Without the Policy?].

205. Jordaan, Foreign Policy Without the Policy?, supra note 204, at 83.

206. H.R.C. Res. 27/32, A/HRC/RES/27/32 (Sept. 24, 2014).

207. John Fisher, The Power of a Positive Vision: How the Human Rights Council Came to Adopt a Majority Resolution on Human Rights, Sexual Orientation, and Gender Identity, INT'L SERV. HuM. RTS. (Apr. 6, 2016), https://www.ishr.ch/news/power-positive-visionhow-human-rights-council-came-adopt-majority-resolution-human-rights-0 (adding that these were not the only states to express opposition. Russia, for example, was also vocal in resisting the resolution).

208. Fisher, supra note 207.

209. H.R.C. Res. 32/2, U.N. Doc. A/HRC/RES/32/2 (June 30, 2016). 
proposed amendments were defeated. ${ }^{210}$ Muntarbhorn duly commenced his mandate, though he stepped down in 2017 due to ill health and was replaced by Victor Madrigal-Borloz. In 2019, the mandate was extended for a further three years with an increased majority in its favour. ${ }^{211}$

\section{Factors driving SOGI progress}

There are several factors which, at key moments, facilitated HRC progress on SOGI initiatives. The first-and most important-was leadership from the Global South. States advocating anti-SOGI positions have often sought to discredit SOGI rights as a Western construct outside the accepted cannon of human rights law, and to characterize pro-SOGI initiatives as Western imperialism. ${ }^{212}$ In order to dismantle this myth and make progress on SOGI issues, leadership had to come from the Global South.

While South Africa's commitment was enough to bring about the 2011 resolution, it could not be sustained in the face of pressure from the African Group. ${ }^{213}$ The comparative success and endurance of the LAC core groups reveals that sharing the leadership burden across a core group can facilitate sustainable and successful leadership on controversial issues. ${ }^{214}$

A second, related, factor is the quality of the leadership. Brazil's diplomacy in 2003 was roundly criticized, with Jordaan describing it as "bumbling." 215 Conversely, the diplomatic efforts of the LAC group have been widely praised as sophisticated, well-planned, and inclusive. Fisher describes the 2014 resolution process as "marked by dedicated outreach, tenacity and conviction." 216 This continued in the lead-up to the 2016 resolution. According to ARC International:

210. Rosa Freedman, U.N. Fight Over LGBT Protection Threatens to Undermine the Human Rights System, THE CONVERSATION (Nov. 4, 2016), http:/ / theconversation.com/un-fight-over-lgbt-protection-threatens-to-underminethe-human-rights-system-68215.

211. See U.N. Doc. A/HRC/41/L.10/Rev.1 (July 10, 2019) (adopting the resolution with 27 in favour, 12 against, and 7 abstentions).

212. M. Joel Voss, Contesting Sexual Orientation and Gender Identity at the U.N. Human Rights Council, 19 Hum. RTS. REV. 1, 20 (2018).

213. See generally Jordaan, Foreign Policy Without the Policy?, supra note 204 (providing a detailed analysis of South Africa's policy positions on SOGI rights at the UN).

214. Jordaan, Foreign Policy Without the Policy?, supra note 204, at 301.

215. Id.

216. Fisher, supra note 207. 
There was open and close consultation with civil society and a willingness to take suggestions on board as well as an effort to get on board the maximum number of states. It is entirely possible that the Asian and African countries which either voted for or abstained on the resolution, did so because the leadership on the SOGI resolution 2016 came from the global south. ${ }^{217}$

Another factor in the success of SOGI resolutions was the appropriate support of Western states. For example, Norway played an influential role in the drafting and adoption of South Africa's 2011 resolution. Similarly, the EU and US lent considerable backing and resources to the LAC groups, including their diplomatic networks. ${ }^{218}$

Engagement by civil society has also been crucial. Lobbying of governments by their domestic civil societies, as well as advocacy by human rights and LGBTI organizations at the HRC, have all influenced the trajectory of SOGI issues. ${ }^{219}$ In 2003, Brazil neglected to liaise with civil society, so NGOs were caught unawares by the tabling of the resolution. Without time to coordinate, travel and lobby, they were unable to bring their influence to bear. In contrast, the LAC core group has worked closely with civil society at the Council, and directly with groups in their own countries. ${ }^{220}$ Collaboration with NGOs, through side panels and group statements, shaped the debate. ${ }^{221}$

Finally, dedicated promotion of SOGI rights by UN leaders, in particular (now former) Secretary-General Ban Ki-moon and (now former) UN High Commissioner for Human Rights, Navi Pillay, played an important role in progress on these issues. Their outspokenness

217. Appointing an Independent Expert on Sexual Orientation and Gender Identity: An Analysis of Process, Results and Implications, ARC INT'L 36 (2016) [hereinafter Appointing an Independent Expert I], http://arc-international.net/wpcontent/uploads/2016/08/HRC32-final-report-EN.pdf.

218. Jordaan, Foreign Policy Without the Policy?, supra note 204, at 304.

219. Dodo Karsay, How Far Has SOGII Advocacy Come at the U.N. and Where is It Heading?, ARC INT'L (2014), https://arc-international.net/wpcontent/uploads/2013/09/How-far-has-SOGII-for-web.pdf.

220. Appointing an Independent Expert on Sexual Orientation and Gender Identity: An Analysis of Process, Results and Implications, ARC INT'L 15 (2016), http://arcinternational.net/wp-content/uploads/2016/08/HRC32-final-report-EN.pdf.

221. John Fisher, The Power of a Positive Vision: How the Human Rights Council Came to Adopt a Majority Resolution on Human Rights, Sexual Orientation, and Gender Identity, INT'L SERV. HUM. RTS. (Apr. 6, 2016), https://www.ishr.ch/news/power-positive-visionhow-human-rights-council-came-adopt-majority-resolution-human-rights-0. 
brought clarity to SOGI norms and encouraged civil society activism. ${ }^{222}$

This case study provides an insight into how some of the Council's political constraints might be overcome, and progress made on contentious topics. The SOGI experience suggests that leadership from the Global South is critical, and that it can be encouraged and buttressed through the building of core leadership groups, appropriate background support from Western countries as well as significant figures like the UN Secretary General and coordinated civil society action.

\section{B. Salvaging the Council}

The preceding analysis of the functioning of the Council, and the SOGI case study, suggest a way forward for the Council.

\section{More principles, less politics}

In an intergovernmental body such as the Council, some degree of politicization is inevitable. The key to a better Human Rights Council is for States to be driven more by principle than by politics. States can and should take measures to mitigate the worst effects of politicization. As Cox observes:

[T] he UN will not be able to have a truly powerful human rights body until a sufficient number of its member states desire it-an outcome unlikely to happen until enough states have improved their human rights records to the point where they are no longer threatened by a powerful HRC. ${ }^{223}$

There will probably always be States that have little intention of observing human rights at home and will therefore seek to undermine the very idea of human rights if they should unfortunately be elected to the Council. The analysis of actual Council membership above indicates that such States are, however, unlikely to ever constitute a number close to a majority. A majority of States do, at least on occasion, seek to respect human rights at home.

Part of the answer, therefore, lies in States aligning their Council

222. Elizabeth Baisley, Reaching the Tipping Point?: Emerging International Human Rights Norms Pertaining to Sexual Orientation and Gender Identify, 38 HuM. RTS. Q. 134, 155-61 (2016); Karsay, supra note 219, at 9-10.

223. Eric Cox, State Interests and the Creation and Functioning of the United Nations Human Rights Council Engagement and Escape: International Legal Institutions and Public Political Contestation, 6 INT’L L. \& INT’L REL. 87, 119 (2010). 
positions with their own professed human rights values. A large number of States embrace human rights standards in their domestic laws but act inconsistently with these values at the Council. For example, South Africa and India, whose constitutions are lauded for their protection and promotion of human rights, nonetheless occasionally embrace roles as "spoilers" at the Council. These States must be held accountable-by other member States and their own domestic civil societies-for acting contrary to their constitutional values on the world stage.

An example of such activism arose with regard to the 2010 General Assembly resolution where the reference to "sexual orientation" was removed from the resolution on arbitrary killings, but swiftly restored six weeks later. While US leadership on the second resolution was crucial, local NGOs rallied to showcase the disgraceful homophobic votes of their own governments. This activism, for example, helped to reverse the votes of Colombia and South Africa, and changed Cuba's vote to an abstention. While lobbying in 2010 failed to change Thailand's original abstention, ${ }^{224}$ that State voted in favor of the groundbreaking SOGI resolution in the Council in 2011.

\section{Leadership from the Global South}

The leadership of the LAC States, and to an extent South Africa, on SOGI issues illustrates the potential for advancing human rights standards and protection with leadership from the Global South. Indeed, with the US withdrawing from the Council, the need for alternative leadership is even greater. Developing States must take ownership of human rights values on the world stage, rather than treat them as a postcolonial football within the broader North/South divide. The strategy of portraying human rights as a Western concept, and therefore sometimes as a form of neo-colonialism, cedes the ground of leadership to Western States. It does not do justice to the progress amongst many developing States on human rights, nor does it acknowledge the grave human rights abuses by Western States which undercut the presumption of "Western values."

Some developing States already lead on certain "pet" issues. For

224. Thailand's Shameful Rejection of Human Rights, THE NATION (Mar. 8, 2011), https://www.asiaone.com/print/News/Latest+News/Asia/Story/A1Story20110308 $-267021 . h t m l$. 
example, while India is generally known for its reticent (and at times hostile) engagement with the Council, it has taken a proactive lead on access to medicine ${ }^{225}$ and human rights and transnational corporations. ${ }^{226}$ It is critical that this sort of leadership extends beyond discreet thematic issues to other issues, including countryspecific situations.

There are signs that a number of developing States are willing to take on a leadership mantle. LAC leadership on SOGI rights is a prime example. Some States from the Global South have also demonstrated a new willingness to adopt condemnatory positions on delinquent States. Brazil has acknowledged that "cooperation won't be able to solve all human rights problems" and that "monitoring activities" and "condemnations" are sometimes necessary. ${ }^{227}$ The principled engagement of countries like Chile, Mexico, Uruguay or Costa Rica in the Latin American Group, and of Botswana, Sierra Leone or Ghana in the African Group, has been pivotal to the ability of the Council to act on a number of country situations. ${ }^{228}$

\section{Retbinking the roles of Western States}

WEOG States must rethink the way in which they engage at the Council. Western States have been most likely to lead on countryspecific situations. However, their ability to build cross- regional support for these initiatives is damaged by their own selectivity and politicization. While the US and others may rightly point to the disproportionate focus on Israel as an example of Council selectivity, their unprincipled shielding of Israel and other allies such as Saudi Arabia is also damning, as are instances of their reflexive rejection of criticism of their own records. Western States seeking to play a leadership role at the Council must themselves be more principled in order to enhance their own credibility and that of the Council.

Western States should also consider how they can best facilitate Southern counterparts to provide principled leadership. A number of

225. H.R.C. Res. 12/24, A/HRC/RES/12/24 (June 17, 2011).

226. H.R.C. Res. 17/4, A/HRC/RES/17/4 (June 27, 2014).

227. Eduard Jordaan, Rising Powers and Human Rights: The India-Brazil-South Africa Dialogue Forum at the UN Human Rights Council, 14 J. HUM. RTS. 463, 465-66 (2015).

228. Philippe Dam, Ten Lessons from 30 Sessions: Improving the Human Rights Council, INT'L SERV. HUM. RTS. (May 26, 2016), http://www.ishr.ch/news/ten-lessons-30sessions-improving-human-rights-council. 
Western states, including the US and Norway, played "backroom" roles which were critical to the success of the SOGI resolutions. By making available their diplomatic networks and Geneva-based resources, Western States can enhance the effectiveness of leadership from the Global South.

True support for Southern leadership will require Western States to surrender some control and show humility. It is not foreseeable that WEOG will somehow gain control of the Council's agenda. If States from the Global South are to take real ownership of human rights, human rights will change and may reflect different priorities. Leadership already comes from the South, just not on the issues of importance to Western States. As noted, India has led on access to medicine. Ecuador is currently leading efforts in the UN Open-Ended Inter-Governmental Working Group to develop "an international legally binding instrument on Transnational Corporations and other business enterprises with respect to human rights" pursuant to resolution $26 / 9$, a move resisted by Western States. ${ }^{29}$

In 2016, the Council passed Resolution 33/14, which established the mandate of the Special Rapporteur on the Right to Development. ${ }^{230} \mathrm{~A}$ broad range of States from the Global South - on a full spectrum from 'good' to 'appalling' human rights actors-voted in favor of the resolution. The UK and France voted against, with the rest of the EU, Eastern Europe, and South Korea abstaining. Interestingly, the EU explained its position by arguing that on the matter of the right to development "diverging views remained and a common position had not been reached so far." The UK stated that although it supported the right to development, it believed that the Human Rights Council agenda was already overloaded and the appointment of a Special Rapporteur would detract from more pressing items. ${ }^{231}$ These objections echo those which were advanced by some States from the Global South in resisting the SOGI mandate. . $32^{2}$

It is important to distinguish between politicized leadership—in which

229. See H.R.C. Res. 26/9, U.N. Doc. A/HRC/RES/26/9 (July 14, 2014).

230. H.R.C. Res. 33/14, U.N. Doc. A/HRC/RES/33/14, 甲ף 14-18 (Oct. 5, 2016).

231. Adriano José Timossi, Special Rapporteur to Monitor the Right to Development, INDEPTH NEWS (Sept. $30 \quad$ 2016), https://archive-2016-2017indepthnews.net/index.php/global-governance/un-insider/702-special-rapporteur-tomonitor-the-right-to-development.

232. Appointing an Independent Expert I, supra note 217, at 50-51, 65. 
an issue is being assertively promoted in order to cynically limit the advancement or protection of human rights, or to undermine the functioning of the Council-and principled leadership with which one may not agree. While the former must be condemned, the latter must be acknowledged and accepted as evidence of the 'ownership' of human rights by the full range of States, and of the proper functioning of the Council.

\section{Crossing Bloc Divides}

Cross-regional cooperation, and the building of cross-regional groups, can strengthen principled engagement. ${ }^{233}$ It signals broad consensus, and mitigates the effect of regional and political blocs and the North/South divide. Close cooperation by States can also enable the pooling of resources and can help 'spread' or share the burden of any backlash. Cross-regional cooperation of this kind depends on States identifying a common human rights concern, then taking active steps to develop the trust necessary to overcome the instinct towards politicization. ${ }^{234}$

An example of the successful use of such a strategy arose over the matter of 'defamation of religions.' From 2001 in the Commission to 2010 in the Council, the OIC had pushed, largely successfully, resolutions on defamation of religions, ${ }^{235}$ against the objections of WEOG. The notion of combating defamation of religions effectively calls upon States to outlaw blasphemy and practices which might cause offence to others on the basis of the latter's religion. The concept of "defamation of religions" extends beyond clear human rights issues such as religious vilification or discrimination on the basis of religion: it verges towards giving religions human rights rather than human beings who adhere to religious beliefs. Such a concept poses unacceptable limitations on freedom of expression ${ }^{236}$ and the free exercise of some religious

233. Allehone Mulugeta Abebe, Of Shaming and Bargaining: African States and the Universal Periodic Review of the United Nations Human Rights Council, 9 HuM. RTS. L. REV. 1, 3 (2009).

234. Yvonne Terlingen, The Human Rights Council: A New Era in U.N. Human Rights Work?, 21 ETHICS INT'L AFF. 167, 178 (2007); Dam, supra note 228.

235. H.R.C. Res. 13/16, U.N. Doc. A/HRC/RES/13/16, I 3 (Apr. 15, 2010); H.R.C. Res. 7/19, U.N. Doc. A/HRC/RES/7/19, ๆ甲 7-9 (Mar. 27, 2008).

236. Right to Freedom of Expression Vital as Algeria Embarks on Reforms - UN Expert, U.N. NEWS (Apr. 19, 2011), https://news.un.org/en/story/2011/04/372722-rightfreedom-expression-vital-algeria-embarks-reforms-un-expert. 
beliefs. $^{237}$

In 2011 the defamation resolution was withdrawn. It was effectively replaced by a resolution on the need to combat religious intolerance and discrimination, matters well within the bounds of human rights law. ${ }^{238}$ That resolution, which had originally been drafted by the US and Egypt and adopted in 2009, was introduced by Pakistan from the OIC and passed by consensus. ${ }^{239}$ Disputes between the IOC and WEOG on this issue have not disappeared. Nevertheless, the US/Egypt cooperation across that divide was crucial in resolving, at least temporarily, a seemingly intractable Council conflict in favor of a much more human rights friendly approach.

\section{Bolstering the participation of NGOS}

Many NGOs wishing to participate in Council activities face significant barriers. Difficulties securing accreditation and visas to travel, threats and reprisals, inadequate funding and resources, limited language skills, lack of familiarity with UN systems and membership of the Geneva "club," and gatekeeping behavior by other NGOs, can prevent an organization from participating, or dilute their impact at the Council. ${ }^{240}$ Some of these barriers have been recognized by the UN: the High Commissioner has called for reform of ECOSOC's NGO Committee. ${ }^{241}$ Yet, the situation in practice remains little changed. ${ }^{242}$

237. Saad Sayeed, Pakistan's Long-persecuted Abmadi Minority Fear Becoming Election Scapegoat, REUTERS (Nov. 15, 2017), https://www.reuters.com/article/us-pakistanelection-ahmadis/pakistans-long-persecuted-ahmadi-minority-fear-becoming-electionscapegoat-idUSKBN1DG04H.

238. H.R.C. Res. 16/18, U.N. Doc. A/HRC/RES/16/18, ๆ甲 1-4 (Mar. 24, 2011).

239. Sejal Parmar, Uprooting 'Defamation of Religions' and Planting a New APPROACH to FreEdom of Expression at the UNITED NATIONS 398 (Tarlach McGonagle \& Yvonne Donders eds., 2015).

240. U.N. Secretary-General, Rep. of Marina Kiai (Special Rapporteur) on Rights to Freedom of Peaceful Assembly and of Association, 197 72-85, U.N. Doc. A/69/365 (Sept. 1, 2014); The Backlash Against Civil Society Access and Participation at the United Nations, INT'L SERV. HuM. RTS. 2, 4-5 (2018), https://www.ishr.ch/news/new-report-backlash-against-civilsociety-access-and-participation-united-nations (last visited Jun. 20, 2019).

241. U.N. Hum. Rts. Council, Rep. of the Off. of the High Comm'r for Hum. Rts., Procedures and Practices in Respect of Civil Society Engagement with International and Regional Organizations, $\mid$ 61, U.N. Doc A/HRC/38/18 (Apr. 18, 2018).

242. U.N. Secretary-General, Cooperation with the United Nations, its Representatives and Mechanisms in the Field of Human Rights, $\uparrow$ T 13-18, U.N. Doc A/HRC/36/31 (Mar. 29, 2018); McEvoy et al., Ending Reprisals Against Those Who Cooperate with the United Nations in the Field of Human Rights: Submission to the UN Secretary-General on Recent Developments, 
Nevertheless, some factors which might increase NGO impact lie (to a greater extent) within the control of civil society itself. It is clear from the example of SOGI rights that NGOs can be instrumental in advancing principled action at the Council. Efforts to build the capacity of domestic organizations to engage with the Council, and better communication and cooperation between NGOs in order to build consensus and align advocacy strategies, enhances effectiveness. ${ }^{243} \mathrm{It}$ is important that NGOs strategically seek out "unusual suspects" for building alliances on particular issues, including other NGOs and developing States. NGOs can support leadership from the Global South by contributing their lobbying efforts and expertise to the cause.

Coordinated action by coalitions of NGOs can also bring pressure to bear on target States both at home and in Geneva, contributing to a better alignment of the State's behavior at the Council with its domestic human rights commitments. It is important that NGOs hold States to account for their behavior on the Council. As seen in the example of the swift reversal of the 2010 UNGA Resolution, States can be lobbied to ensure that their votes reflect their professed human rights values at home. A greater alignment between those values and a State's Council performance can be enough to turn regressive Council majorities into progressive Council majorities.

\section{CONCLUSION}

The year of 2006 was not an ideal time in which to transform the Commission into the Council and open up the opportunity to revise the previous UN human rights acquis. ${ }^{244}$ International tensions ran high, and the human rights record of the evangelizing West smacked of extreme hypocrisy. Rendition, torture, arbitrary detention, and other human rights violations characterized much of the West's participation in "the War on Terror," The ongoing war in Iraq, which

Cases and Recommendations, INT'L SERV. HuM. RTS. 7 (May 2017), https://www.ishr.ch/sites/default/files/documents/reprisals_submission_may_2017 _final_updated.pdf.

243. Dodo Karsay, How Far Has SOGII Advocacy Come at the U.N. and Where is It Heading?, ARC INT'L (2014), https://arc-international.net/wpcontent/uploads/2013/09/How-far-has-SOGII-for-web.pdf.; HILARY CHARLESWORTH \& EMMA LARKING, HUMAN RIGHTS AND THE UNIVERSAL PERIODIC REVIEW 126 (2014).

244. Schrijver, supra note 1 , at 817 . 
persisted after an illegal invasion in 2003, drove particular enmity against the US and the UK. The confrontational US attitude within the UN from its UN Ambassador, John Bolton, meant that that country played no meaningful role in the birth of the Council. Given all of these difficulties at its inception, the Council may have turned out as well as could have been hoped for.

Fast-forwarding to 2019, we find ourselves at a similar juncture. Current discourse gives the distinct impression that human rights - its norms, institutions and movement - are in serious crisis. The rise of populism, ${ }^{245}$ the decline in leadership and adherence to human rights values, ${ }^{246}$ and the capacity of human rights to respond to the most pressing issues of our times, ${ }^{247}$ have all been posited as fundamental threats to the legitimacy and relevance of human rights. The US withdrawal from the Council epitomizes this phenomenon, with its hubristic rejection of multilateralism. John Bolton was even back in the US administration from 2018 to 2019, in the even more powerful role of National Security adviser.

Between 2006 and 2019, there have been more hopeful years on the human rights front. While the Arab Spring looks to have soured

245. Philip Alston, The Populist Challenge to Human Rights, 91 Hum. RTS. PRAC. 1 (2017); Kenneth Roth, The Pushback Against the Populist Challenge, Hum. RTS. Watch (2017), https://www.hrw.org/world-report/2018/pushback-against-the-populistchallenge; Rising to the Populist Challenge: A NeW PlayboOK fOr Human RighTS ACTORS 16 (César Rodriguez-Garavito \& Krizna Gomezet eds., 1st ed. 2018).

246. Amnesty International Report 2017/18: The State of the World's Human Rights, AMNESTY INT'L https://www.amnesty.org/download/Documents/POL1067002018ENGLISH.PDF; Rule of Law Index 2017-2018, WORLD Just. PROjECT (2018), https://worldjusticeproject.org/sites/default/files/documents/WJP-ROLI-2018June-Online-Edition_0.pdf; Jasmine L. Tyler \& Thomas J. Rachko, Jr., U.S. Turning Its Back on Human Rights: Withdrawal from U.N. Mirrors Abuses at Home, HUM. RTS. WATCH (June 29, 2018), https://www.hrw.org/news/2018/06/29/us-turning-its-back-humanrights\#.

247. SAmuel Moyn, Not EnOUgh: Human RightS IN AN UNEQUal World xxii (Belknap Press 2018); Salil Tripathy, Is Human Rights Advocacy Off Track?, INST. HuM. RTS. \& Bus. (Apr. 30, 2018), https://www.ihrb.org/other/governmentsrole/commentary-is-human-rights-advocacy-off-track; Gaby Oré Aguilar \& Ignacio Saiz, Tackling Inequality as Injustice: Four Challenges for the Human Rights Agenda, CTR. ECON. \& SOC. RTS. (Mar. 30, 2016), http://www.cesr.org/tackling-inequality-injustice-fourchallenges-human-rights-agenda; Stephen Humphreys, Climate Change Poses an Existential Threat to Human Rights, OPEN GLOB. RTS. (July 16, 2019), https://www.opendemocracy.net/en/openglobalrights-openpage/climate-changehighlights-fragility-of-human-rights-norms/. 
in hindsight, the Council adopted a noticeably more progressive agenda in light of its advent in 2011. ${ }^{248}$ Unsurprisingly, the Council responds to the environment around it. Or, rather, its members do. And this distinction is crucial-the Council's faults are essentially those of its members, rather than of the abstract entity that is the Council.

In 2007, early on in the Council's life, the deputy Secretary General of the UN, Louise Frechet, stated:

To a certain extent we have sought institutional responses, institutional fixes, through reform to problems that are more fundamental and more political. ... The Human Rights Commission was deemed to be ineffective by a lot of countries. The answer was to transform it into a new institution called the Human Rights Council. But it's not performing all that much better than the Human Rights Commission because the world is composed of countries that have very different views on human rights. And unless there's real political action to really strengthen the solidarity of all the countries that do believe in human rights across the North-South divide, you shouldn't be surprised that you have the exact same results. I think there's not enough attention paid to building this political consensus among countries that share the same views, and too much on the machinery. ${ }^{249}$

In the current international environment, which is hostile to multilateralism, the importance of forums such as the Human Rights Council, which bring States of all kinds together to discuss and debate, is greater than ever. States must factor into their decision-making how excessive politicization and selectivity, which all are guilty of to a greater and lesser extent, risks sending the Council the way of its predecessor. States, and also NGOs, must be prepared to undertake the hard diplomatic and lobbying work of crossing divides, and unearthing likeminds amongst the non-like-minded, in order to achieve multilateral human rights progress.

248. Rosa Freedman \& Ruth Houghton, Two Steps Forward, One Step Back: Politicisation of the Human Rights Council, 17 Hum. RTS. L. REV. 753, 754 (2017).

249. Yvonne Terlingen, The Human Rights Council: A New Era in U.N. Human Rights Work?, 21 ETHICs INT’L AFF. 167, 178 (2007) (quoting Louise Frechette, former UN Deputy Secretary-General, from an interview in January 2007). 